\title{
Mechanical Properties and Microstructure of Geopolymer Binder Based on Umeanyar Slatestone Powder
}

\author{
Ni Kadek Astariani ${ }^{1,2, *}$, I Made Alit Karyawan Salain ${ }^{3}$, I Nyoman Sutarja ${ }^{3}$, Ida Bagus Rai Widiarsa ${ }^{3}$ \\ ${ }^{1}$ Doctoral Program Engineering Science, Udayana University, Denpasar, Indonesia \\ ${ }^{2}$ Faculty of Science and Technology, Ngurah Rai of University, Denpasar, Indonesia \\ ${ }^{3}$ Department of Civil Engineering, Udayana University, Badung, Indonesia
}

Received June 12, 2021; Revised July 12, 2021; Accepted August 22, 2021

\begin{abstract}
Cite This Paper in the following Citation Styles
(a): [1] Ni Kadek Astariani, I Made Alit Karyawan Salain, I Nyoman Sutarja, Ida Bagus Rai Widiarsa, "Mechanical Properties and Microstructure of Geopolymer Binder Based on Umeanyar Slatestone Powder, "Civil Engineering and Architecture, Vol. 9, No. 6, pp. 1698-1716, 2021. DOI: 10.13189/cea.2021.090604.
\end{abstract}

(b): Ni Kadek Astariani, I Made Alit Karyawan Salain, I Nyoman Sutarja, Ida Bagus Rai Widiarsa (2021). Mechanical Properties and Microstructure of Geopolymer Binder Based on Umeanyar Slatestone Powder. Civil Engineering and Architecture, 9(6), 1698-1716. DOI: 10.13189/cea.2021.090604.

Copyright $\bigcirc 2021$ by authors, all rights reserved. Authors agree that this article remains permanently open access under the terms of the Creative Commons Attribution License 4.0 International License

\begin{abstract}
This research focuses on the mechanical and microstructure properties of geopolymer binder with slatestone waste as the base material. This geopolymer binder comes from industrial waste crushing slate in the Umeanyar area. This waste is processed into stone powder (USSP) which contains $\mathrm{SiO}_{2}(49 \%), \mathrm{Al}_{2} \mathrm{O} 3(11 \%), \mathrm{CaO}$ (11.2\%). This USSP uses a sodium hydroxide (SS) activator with a concentration of $14 \mathrm{M}$. The proportion of the mixture of precursor and activator (P/A) is $70 \%: 30 \%$; 75\%: $25 \% ; 80 \%: 20 \%$ and alkaline activator $\mathrm{Na}_{2} \mathrm{SiO}_{3}$ : $\mathrm{NaOH}(\mathrm{SS} / \mathrm{SH})$ of $1: 1 ; 1.5: 1 ; 2: 1$, by weight. Samples of specimens were made in the form of a cube with a side of $50 \mathrm{~mm}$ and tested at the age of 7 and 28 days. Mechanical properties tested include density and compressive strength based on ASTM-C39. Meanwhile, the microstructural analysis used X-Ray Diffraction (XRD) and Scanning Electronic Microscope-Energy Dispersive X-Ray (SEM-EDX) analysis. The results of the density test were $1.90 \mathrm{~g} / \mathrm{cm}^{3}$ and $1.85 \mathrm{~g} / \mathrm{cm}^{3}$ respectively and the compressive strength test results were $7.40 \mathrm{MPa}$ and $12.73 \mathrm{MPa}$ at the age of 7 and 28 days, respectively.
\end{abstract}

\begin{tabular}{|c|c|c|}
\hline $\begin{array}{l}\text { Keywords } \\
\text { Microstructure, }\end{array}$ & $\begin{array}{l}\text { Compressive } \\
\text { Geopolymer }\end{array}$ & $\begin{array}{l}\text { Strength, } \\
\text { Binder, }\end{array}$ \\
\hline
\end{tabular}

\section{Introduction}

Concrete is one of the materials needed in the construction sector. The constituent materials of concrete generally consist of cement, aggregate, and water, if necessary there are materials added to change certain properties of the concrete [1]. The use of Portland cement as a concrete-forming material, in its production, requires a very large amount of energy due to heating to a temperature of $1500^{\circ} \mathrm{C} \quad[2-9]$. The cement-forming materials consist of limestone $\left(\mathrm{CaCO}_{3}\right)$, silica sand/clay $\left(\mathrm{SiO}_{2}\right.$ and $\left.\mathrm{Al}_{2} \mathrm{O}_{3}\right)$, and iron oxide $\left(\mathrm{Fe}_{2} \mathrm{O}_{3}\right)$. These raw materials are processed through heating and calcination to release carbon dioxide gas $\left(\mathrm{CO}_{2}\right)$ which is the main contributor to greenhouse gas emissions in the atmosphere [10]. The product in the form of granules in the form of gray marbles with a diameter of about $2 \mathrm{~cm}$ is called Portland cement clinker The production of each tonne of cement clinker including its fuel is almost equivalent to one ton of $\mathrm{CO}_{2}$ gas released into the atmosphere [2,5]. In recent years, the world's cement production has been recorded at 4 billion tons per year, which means about 4 billion tons of $\mathrm{CO}_{2}$ gas has been released into the atmosphere every year $[9,10]$. With the results of $\mathrm{CO}_{2}$ gas emissions that are quite large and have harmed the environment, the mitigation action that can be taken is to reduce the use of cement in the manufacture of concrete. 
Geopolymer binder is a geosynthetic binder that uses materials that are not derived from cement. The term geopolymer was first introduced by Davidovits in 1978 who found a polymerization bond between alkaline activators and the main ingredients in the form of fly ash and rice husk ash [13-15]. Geopolymer is the synthesis of natural materials through a polymerization process with the main ingredients in the manufacture of geopolymer materials are materials containing silica and alumina elements $[12,15-16]$. The raw material in this geopolymer binder is called a precursor.

The precursors in the geopolymer binder are the main ingredients that are rich in alumina and silica. The raw materials or precursors of geopolymers usually use fly ash, rice husk ash, metakaolin, white clay, or other materials that contain a lot of silica and alumina. The effect of using this precursor can affect the physical and mechanical properties of the geopolymer binder. Research on the use of fly ash as a precursor containing more than $50 \%$ silica and alumina activated with an activator solution can to produce compressive strength exceeding conventional cement [18-22].

In this study, slatestone waste was used as a geopolymer binder precursor. Slatestone is generally referred to as slatestone and belongs to the metamorphic or metamorphic rock group [23]. Slatestone has physical characteristics that are slate with regular thickness, shiny and hard, often found in mountainous areas, one of which is in the Umeanyar area. Until now, slatestone is not only used as a building material (coarse aggregate) or wall and floor decoration material. The use of slatestone for the roofs of buildings is in many areas of Galicia, Spain [24].

The stone crusher industry in the area processes slatestones of various sizes $(1-4 \mathrm{~cm})$ depending on consumer demand. This stone-cutting business results in useless parts becoming waste that accumulates and even builds up so that it can disrupt the local environment. A preliminary research study on the mineral content in slatestones has been carried out by Karyasa [25]. The results of the study showed that slatestone contains $37 \%$ silica, $11.13 \%$ aluminum, $12.3 \%$ calcium, $5.47 \%$ iron and, $34.1 \%$ other metals. With the high content of silica and alumina minerals, these materials have the potential to be used as an alternative as a geopolymer precursor. The slatestone waste will be processed into powder which is used as a precursor by using $\mathrm{NaOH}$ and $\mathrm{Na}_{2} \mathrm{SiO}_{3}$ as alkaline activators in the manufacture of geopolymer binder.

In the manufacture of geopolymers, many factors affect the characteristics of the resulting geopolymer both mechanically, physically, and microstructured, including raw materials or precursors, calcination temperature/thermal treatment, particle size, activating solution/activator, and the treatment process [12, 24-28]. The results of the compressive strength test as one of the mechanical properties of the binder are very important as a parameter of a test object. Several studies have been carried out using several precursors activated with alkaline activators [31-36]. In addition to compressive strength as a mechanical property of binders, physical properties also need to be considered in the manufacture of geopolymer binders. One of them is the volume weight or theoretical weight of the test object can be determined by dividing the weight by the volume of the test object [37].

Activation of the precursor by providing an alkaline activator to a mixture of geopolymer binders with a certain ratio of sodium silicate (SS) and sodium hydroxide (SH) can affect the results of the compressive strength test. Research using fly ash, crushed stone dust, lunar rock sand as precursors have been carried out and give an increase in compressive strength when the $\mathrm{SS} / \mathrm{SH}$ ratio increases [7, 29-30]. The increase in compressive strength also occurs when the age of the test object increases when tested. This is evidenced by the test specimens aged 7 and 28 days [31-32], the compressive strength produced by each specimen at the age of 28 days is higher than at the age of 7 days. The effect of the ratio of precursors and activators ( $\mathrm{P} / \mathrm{A})$ also affects the compressive strength of geopolymer binders. The greater the $\mathrm{P} / \mathrm{A}$ ratio, the higher the compressive strength value \{Formatting Citation\}. As for the mechanical property in the form of volume weight, the value increases when the $\mathrm{P} / \mathrm{A}$ and $\mathrm{SS} / \mathrm{SH}$ ratios increase [35-37]. In addition to mechanical properties in the form of compressive strength and volume weight tests, this study will also discuss the microstructure of geopolymer binders based on Umeanyar slatestone powder. Microstructural tests were carried out using X-RD (X-Ray Diffraction) and SEM (Scanning Electronic Microscope).

\section{Materials and Methods}

\subsection{Materials}

The precursor used in this study was Umeanyar slatestone powder (USSP). The material sample is sieve at $200 \mu \mathrm{m}$ (Figure 1). The results of the XRF analysis of Umeanyar slatestone powder are shown in Figure 2 and Table 1. From the results of XRF analysis, the mineral content contained in USSP consists of $\mathrm{SiO}_{2}(49 \%), \mathrm{Al}_{2} \mathrm{O}_{3}$ (11\%), $\mathrm{CaO}(11.2 \%), \mathrm{Fe}_{2} \mathrm{O}_{3}$ (22.35\%), and 6.45 other oxide minerals. With silica and alumina content of more than $50 \%$, it is expected to produce good geopolymer precursors. There are two types of alkaline activators used, namely sodium silicate $\left(\mathrm{Na}_{2} \mathrm{SiO}_{3}\right)$ and sodium hydroxide $(\mathrm{NaOH})$. The concentration of sodium hydroxide $(\mathrm{SH})$ solution was $14 \mathrm{M}$. The criteria for selecting the proportion of geopolymer binder are based on several studies that have been carried out previously which resulted in high compressive strength. Geopolymer binder 
was made with 3 variations of precursor and activator (P/A), namely 70\%:30\%; 75\%:25\%; 80\%:20\%. Meanwhile, the ratio of sodium silicate and sodium hydroxide $(\mathrm{SS} / \mathrm{SH})$ activator is $1: 1 ; 1.5: 1 ; 2: 1$.

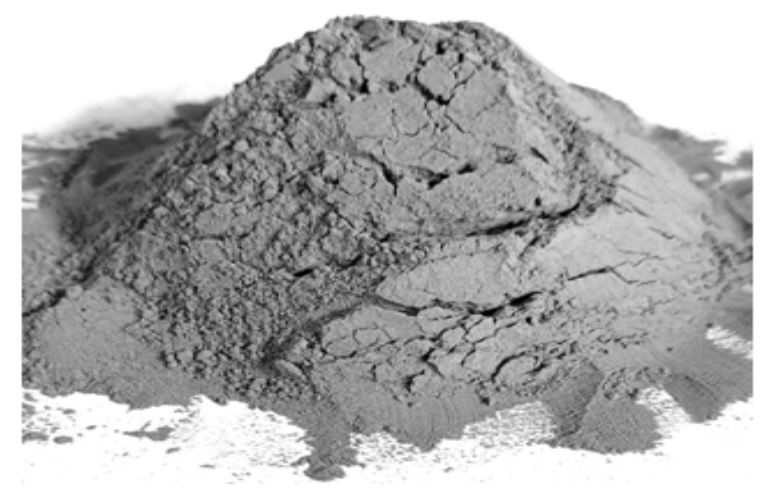

(Source: Author, 2021)

Figure 1. Umeanyar slatestone powder
Table 1. XRF of Umeanyar slatestone powder (USSP)

\begin{tabular}{cc}
\hline Compound & Percentage (\%) \\
\hline $\mathrm{Al}_{2} \mathrm{O}_{3}$ & 11,00 \\
$\mathrm{~S}_{\mathrm{i}} \mathrm{O}_{2}$ & 49,00 \\
$\mathrm{~K}_{2} \mathrm{O}$ & 3,37 \\
$\mathrm{CaO}$ & 11,20 \\
$\mathrm{TiO}_{2}$ & 2,06 \\
$\mathrm{~V}_{2} \mathrm{O}_{5}$ & 0,03 \\
$\mathrm{MnO}$ & 0,55 \\
$\mathrm{Fe}_{2} \mathrm{O}_{3}$ & 22,35 \\
$\mathrm{CuO}_{20}$ & 0,14 \\
$\mathrm{ZnO}$ & 0,04 \\
$\mathrm{Rb}_{2} \mathrm{O}$ & 0,04 \\
$\mathrm{SrO}$ & 0,17 \\
$\mathrm{ZrO}_{2}$ & 0,12 \\
$\mathrm{BaO}_{2}$ & 0,20 \\
$\mathrm{Re}_{2} \mathrm{O}_{7}$ & 0,04 \\
\hline
\end{tabular}

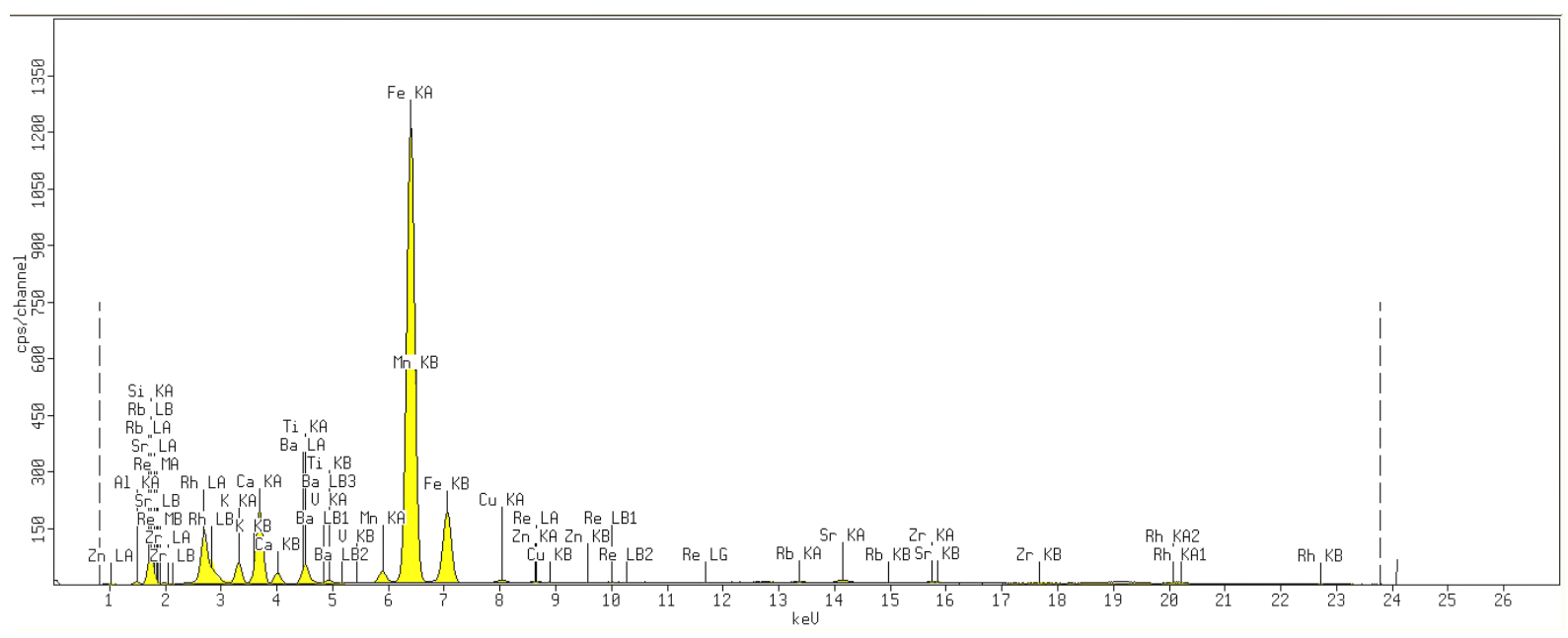

(Source: Lab. Malang, 2021)

Figure 2. XRF of Umeanyar slatestone powder 


\subsection{Density}

The weight of the volume or the theoretical weight of the test object can be determined by dividing the weight by the volume of the test object [37]. The volume weight of the geopolymer binder test object can be formulated by equation (1) below:

$$
W_{p}=\frac{W_{r}}{V}
$$

$$
\begin{aligned}
& \text { by: } \\
& \mathrm{W}_{\mathrm{p}} \quad=\text { density }\left(\mathrm{g} / \mathrm{cm}^{3}\right) \\
& \mathrm{W}_{\mathrm{r}} \quad=\text { weight of the sample }(\mathrm{g}) \\
& \mathrm{V}=\text { volume of the sample }\left(\mathrm{cm}^{3}\right)
\end{aligned}
$$

\subsection{Compressive Strength}

Compressive strength is the amount of load per unit area that causes the test object to crumble when it is loaded with the compressive force generated by the press machine. The testing process begins by placing the test object into the compressive strength testing machine, but the slate surface of the test object is placed on the top base. The compressive strength testing machine is turned on, wait a few seconds for the test object to crack. The compressive strength test is intended to determine the actual compressive strength value of the binder sample under hard conditions using a compressive strength testing machine until the sample is completely crushed [44]. The value of the binder compressive strength can be calculated by equation (2) as follows:

$$
\sigma=\frac{P}{A}
$$

by:

$$
\begin{aligned}
& \sigma=\text { Compressive strength }\left(\mathrm{N} / \mathrm{mm}^{2} \text { or } \mathrm{MPa}\right) \\
& \mathrm{P}=\text { Ultimate Load }(\mathrm{N}) \\
& \mathrm{A}=\text { Cross-sectional area }\left(\mathrm{mm}^{2}\right)
\end{aligned}
$$

\subsection{Microstructure Analysis}

After the volume weight is measured and a compressive test is carried out on the geopolymer binder, the flakes of the specimen will be tested for XRD and SEM-EDX microstructures. XRD is a tool used to characterize the crystal structure, crystal size of a solid material. All materials containing certain crystals when analyzed using XRD will show specific peaks. Diffraction methods are generally used to identify unknown compounds contained in a solid by comparing the diffraction data with the database released by the International Center for Diffraction Data in the Powder Diffraction File (PDF).
While the SEM-EDX test is a type of microstructural testing using an electron microscope that uses an electron beam to describe the surface shape of the material being analyzed. The working principle of this SEM is to describe the surface of an object or material with a reflected electron beam with high energy. The surface of the material that is irradiated or exposed to the electron beam will reflect the electron beam or called a secondary electron beam in all directions. But of all the reflected electron beams there is one electron beam that is reflected with the highest intensity. The detector contained in the SEM will detect a high-intensity electron beam reflected by the object or material being analyzed. Besides that, it can also take advantage of the reflected beam from the object so that information can be known by using an image processing program contained in the computer.

\subsection{Mixing Geopolymer Binder}

The USSP-based geopolymer binder was prepared first by making an alkaline solution by mixing the $14 \mathrm{M}$ sodium hydroxide activator alkaline which had been left for 24 hours previously with a sodium silicate solution according to the ratios listed in Table 2. The USSP precursor was put into a 3-liter bowl mixer. Turn on low speed for 15 seconds, then add an alkaline activator and turn the mixer on medium speed again for 30 seconds and mix well. After thoroughly mixed, prepare a cube mold with a side of $50 \mathrm{~mm}$ (Figure 3). After being printed into the mold, tightly wrapped in airtight plastic for 24 hours. After being allowed to stand for 24 hours, the cube test object was put into an oven at a temperature of $70^{\circ} \mathrm{C}$ for 24 hours. After being removed from the oven, the specimens were removed from the mold and tested at the age of 7 days and 28 days. For each variation, 3 specimens were made, and the tests were carried out according to the standards of SNI 2008 [37] and ASTM C39 [44].

Table 2. Mixing geopolymer binder of USSP

\begin{tabular}{|c|c|c|c|}
\hline \multirow{3}{*}{ Group } & Code & P/A & SS/SH \\
\hline \multirow{3}{*}{1} & Y11 & $70 \%: 30 \%$ & $1: 1$ \\
\cline { 2 - 4 } & $\mathrm{Y} 12$ & $70 \%: 30 \%$ & $1,5: 1$ \\
\cline { 2 - 4 } & $\mathrm{Y} 13$ & $70 \%: 30 \%$ & $2: 1$ \\
\hline \multirow{3}{*}{2} & $\mathrm{Y} 21$ & $75 \%: 25 \%$ & $1: 1$ \\
\cline { 2 - 4 } & $\mathrm{Y} 22$ & $75 \%: 25 \%$ & $1,5: 1$ \\
\cline { 2 - 4 } & $\mathrm{Y} 23$ & $75 \%: 25 \%$ & $2: 1$ \\
\hline \multirow{3}{*}{3} & $\mathrm{Y} 31$ & $80 \%: 20 \%$ & $1: 1$ \\
\cline { 2 - 4 } & $\mathrm{Y} 32$ & $80 \%: 20 \%$ & $1,5: 1$ \\
\cline { 2 - 4 } & $\mathrm{Y} 33$ & $80 \%: 20 \%$ & $2: 1$ \\
\hline
\end{tabular}




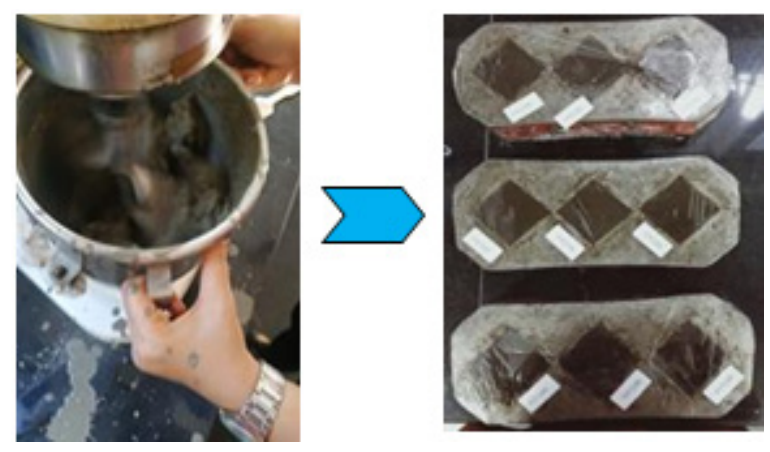

(Source: Author, 2021)

Figure 3. Mixing geopolymer of USSP

\section{Results and Discussion}

\subsection{Density Test}

The results of the density test are presented in Figures 4-10 and Tables 3-4. Each according to variation with the ratio of $\mathrm{P} / \mathrm{A}$ and $\mathrm{SS} / \mathrm{SH}$ with an increase in age of 7 and 28 days.
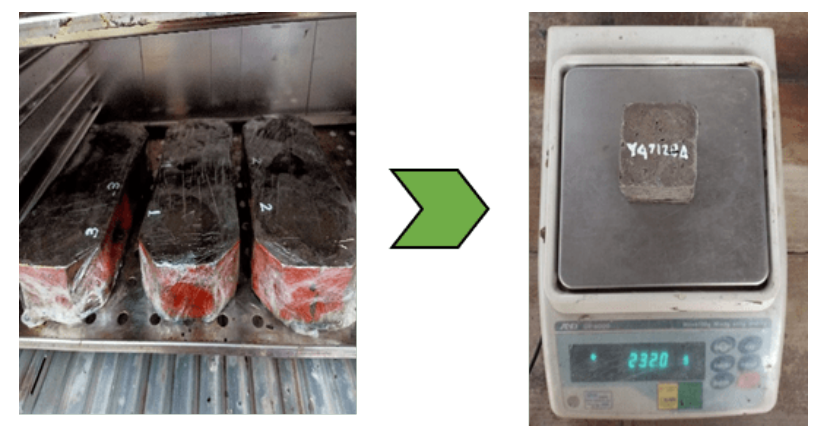

(Source: Author, 2021)

Figure 4. Density test

\subsubsection{Precursor to activator ratio}

The results of the density test showed that with an increase in the $\mathrm{P} / \mathrm{A}$ ratio, the volume weight value increased at the age of 7 and 28 days. In the $1: 1 \mathrm{SS} / \mathrm{SH}$ group, the lowest volume weight was $1.75 \mathrm{~g} / \mathrm{cm}^{3}$ at the age of 7 days and decreased to $1.71 \mathrm{~g} / \mathrm{cm}^{3}$ at the age of 28 days. Meanwhile, the highest volume weight was in the $2: 1 \mathrm{SS} / \mathrm{SH}$ group with a $\mathrm{P} / \mathrm{A}$ ratio of $80 \%: 20 \%$ with a value of $1.90 \mathrm{~g} / \mathrm{cm}^{3}$ and $1.85 \mathrm{~g} / \mathrm{cm}^{3}$ at the age of 7 and 28 days, respectively. This shows that the increasing percentage of precursors causes an increase in the volume weight of the geopolymer binder [45]. The precursor with the highest amount $(80 \%)$ contributed to the high volume weight of the geopolymer binder mixture because the amount of solid content was more than the amount of liquid contributed by the alkaline activator in the amount of $20 \%$. So along with the increase in age from 7 to 28 days, the polymerization bond reaction continues so that the volume weight when the specimen is 28 days old decreases [46-48].

Table 3. Density results for $\mathrm{P} / \mathrm{A}$ ratio

\begin{tabular}{|c|c|c|c|c|}
\hline Code & $\mathbf{P} / \mathbf{A}$ & SS/SH & $\begin{array}{c}7 \text { days } \\
\left(\mathrm{g} / \mathrm{cm}^{3}\right)\end{array}$ & $\begin{array}{l}28 \text { days } \\
\left(\mathrm{g} / \mathrm{cm}^{3}\right)\end{array}$ \\
\hline D11 & $70 \%: 30 \%$ & $1: 1$ & 1,75 & 1,71 \\
\hline $\mathrm{D} 21$ & $75 \%: 25 \%$ & $1: 1$ & 1,83 & 1,78 \\
\hline D31 & $80 \%: 20 \%$ & $1: 1$ & 1,85 & 1,82 \\
\hline $\mathrm{D} 12$ & $70 \%: 30 \%$ & $1,5: 1$ & 1,79 & 1,75 \\
\hline D22 & $75 \%: 25 \%$ & $1,5: 1$ & 1,85 & 1,79 \\
\hline D32 & $80 \%: 20 \%$ & $1,5: 1$ & 1,88 & 1,84 \\
\hline D13 & $70 \%: 30 \%$ & $2: 1$ & 1,87 & 1,80 \\
\hline D23 & $75 \%: 25 \%$ & $2: 1$ & 1,89 & 1,81 \\
\hline D33 & $80 \%: 20 \%$ & $2: 1$ & 1,90 & 1,85 \\
\hline
\end{tabular}

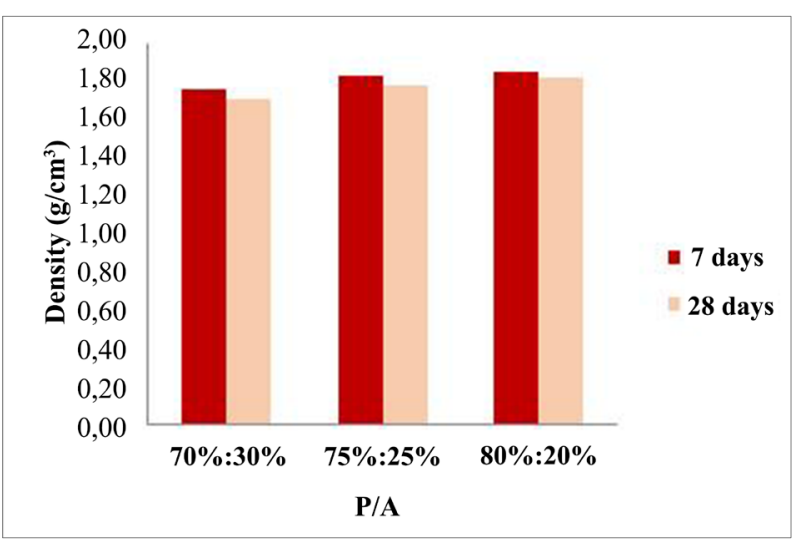

Figure 5. Density results of geopolymer binder $(\mathrm{SS} / \mathrm{SH}=1: 1)$

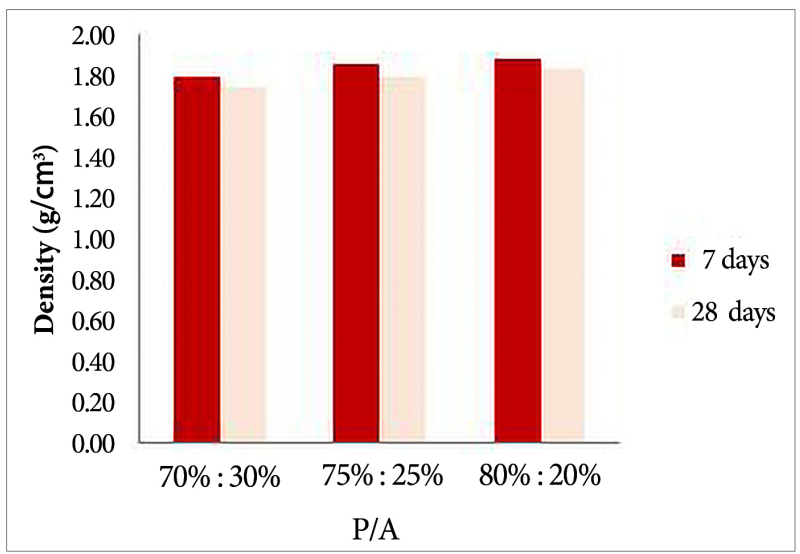

Figure 6. Density results of geopolymer binder $(\mathrm{SS} / \mathrm{SH}=1,5: 1)$ 


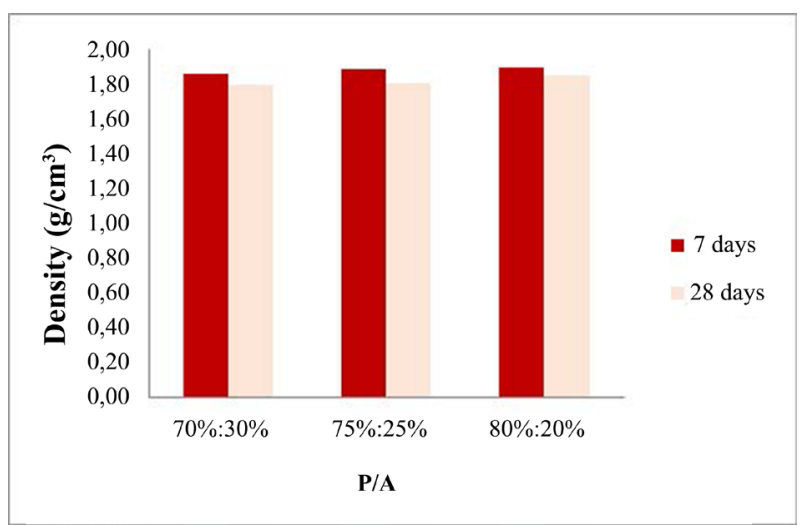

Figure 7. Density results of geopolymer binder $(\mathrm{SS} / \mathrm{SH}=2: 1)$

\subsubsection{Sodium silicate to sodium hydroxide ratio}

Increasing the SS/SH ratio can affect the density value of geopolymer binders with USSP base materials. This can be seen in Tables 4 and Figures 8-10. The more the value of the $\mathrm{SS} / \mathrm{SH}$ ratio increases, the density value of the test object also increases. The average increase occurred in each group with the highest density value at a $2: 1$ $\mathrm{SS} / \mathrm{SH}$ ratio of $1.87 \mathrm{~g} / \mathrm{cm}^{3}, 1.89 \mathrm{~g} / \mathrm{cm}^{3}$, and $1.9 \mathrm{~g} / \mathrm{cm}^{3}$ at the age of 7 days. Meanwhile, at the age of 28 days, the average density of the specimens decreased. During the geopolymerization reaction process until the age of 28 days, the decrease in density occurred slowly. Evaporation that occurs during the binding process is also the cause of the decrease in density. This is due to water loss on the binder surface, and the initial bonding process is faster $[26,34,41-42]$.

In group 1 (Table 4), the lowest density value was 1.71 $\mathrm{g} / \mathrm{cm}^{3}$ and the highest was in group 3, which was 1.85 $\mathrm{g} / \mathrm{cm}^{3}$. The increase in density values in each group with variations in $\mathrm{SS} / \mathrm{SH}$ was caused by the increase in the alkaline activator content, especially the increasing $\mathrm{SS} / \mathrm{SH}$ ratio. However, the results of the density of each test object along with the increase in the value of the SS/SH ratio, are not too large, namely an average of $2 \%$. So the $\mathrm{SS} / \mathrm{SH}$ ratio factor in geopolymer binders contributes less to the density increase [42].

Table 4. Density results for SS/SH ratio

\begin{tabular}{|c|c|c|c|}
\hline \multirow{2}{*}{ Group } & Code & $\mathbf{7}$ days & $\mathbf{2 8}$ days \\
\hline \multirow{3}{*}{1} & $\mathrm{D} 11$ & 1,75 & 1,71 \\
\cline { 2 - 4 } & $\mathrm{D} 12$ & 1,79 & 1,75 \\
\cline { 2 - 4 } & $\mathrm{D} 13$ & 1,87 & 1,80 \\
\hline \multirow{3}{*}{2} & $\mathrm{D} 21$ & 1,83 & 1,78 \\
\cline { 2 - 4 } & $\mathrm{D} 22$ & 1,85 & 1,79 \\
\cline { 2 - 4 } & $\mathrm{D} 23$ & 1,89 & 1,81 \\
\hline \multirow{3}{*}{3} & $\mathrm{D} 31$ & 1,85 & 1,82 \\
\cline { 2 - 4 } & $\mathrm{D} 32$ & 1,88 & 1,84 \\
\cline { 2 - 4 } & $\mathrm{D} 33$ & 1,90 & 1,85 \\
\hline
\end{tabular}

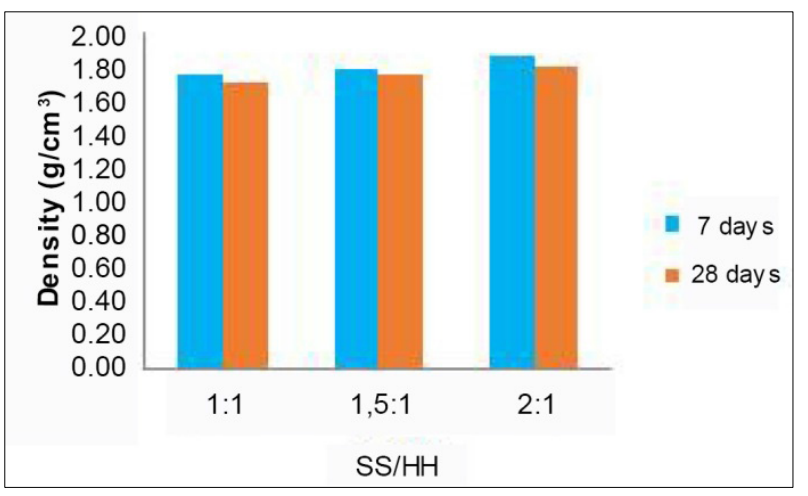

Figure 8. Density results of sample D1 (70\%:30\%)

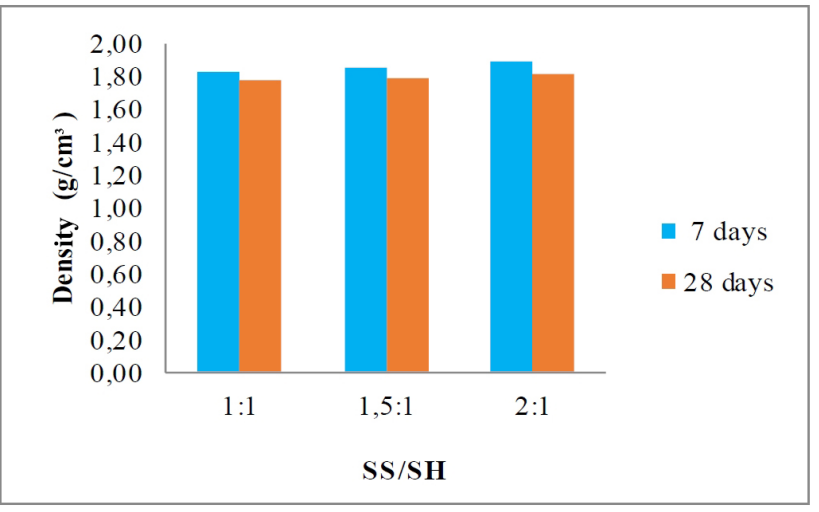

Figure 9. Density results of sample D2 (75\%:25\%)

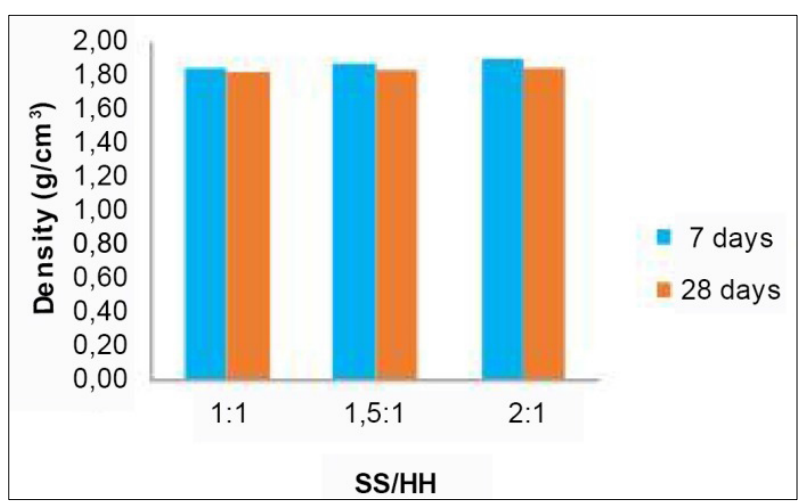

Figure 10. Density results of sample D3 (80\%:20\%)

\subsection{Compressive Strength Test}

3.2.1. Precursor to activator ratio
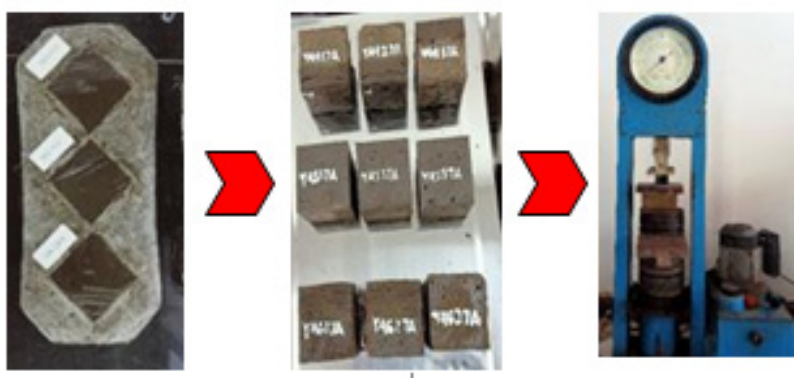

(Source: Author, 2021)

Figure 11. Compressive strength test 
The increase in the P/A ratio affects the compressive strength of geopolymer binders. The value of the compressive strength of each variation of the test object is shown in Tables 5 and Figures 11-14.

The increase in the compressive strength value occurs with every increase in the $\mathrm{P} / \mathrm{A}$ ratio. The percentage increase in compressive strength values is between $10-15 \%$ for each increase in the $\mathrm{SS} / \mathrm{SH}$ ratio at the age of 7 days. While at the age of 28 days, the percentage increase almost reached $40 \%$. The highest compressive strength of $12.73 \mathrm{MPa}$ is in the test object coded D33 with the highest $\mathrm{P} / \mathrm{A}$ ratio of $80 \%: 20 \%$. The greater the $\mathrm{P} / \mathrm{A}$ ratio, the higher the compressive strength of the geopolymer binder as it ages. The use of a precursor of slatestone powder at $80 \%: 20 \% \mathrm{P} / \mathrm{A}$ composition has the highest compressive strength. This is because, at this ratio, the binder has the highest silica and alumina content compared to other $\mathrm{P} / \mathrm{A}$ ratios. In addition to producing a denser binder structure, the high $\mathrm{P} / \mathrm{A}$ content can contribute to increasing the compressive strength of geopolymer binders [43-44].

Table 5. Compressive strength results for $\mathrm{P} / \mathrm{A}$ ratio

\begin{tabular}{|c|c|c|c|c|}
\hline Code & P/A & SS/SH & $\begin{array}{c}\text { 7 days } \\
\text { (MPa) }\end{array}$ & $\begin{array}{c}\text { 28 days } \\
\text { (MPa) }\end{array}$ \\
\hline D11 & $70 \%: 30 \%$ & $1: 1$ & 4,80 & 6,00 \\
\hline D21 & $75 \%: 25 \%$ & $1: 1$ & 5,20 & 6,60 \\
\hline D31 & $80 \%: 20 \%$ & $1: 1$ & 6,07 & 8,07 \\
\hline D12 & $70 \%: 30 \%$ & $1,5: 1$ & 5,67 & 6,53 \\
\hline D22 & $75 \%: 25 \%$ & $1,5: 1$ & 6,13 & 7,27 \\
\hline D32 & $80 \%: 20 \%$ & $1,5: 1$ & 6,73 & 9,53 \\
\hline D13 & $70 \%: 30 \%$ & $2: 1$ & 6,93 & 8,13 \\
\hline D23 & $75 \%: 25 \%$ & $2: 1$ & 6,93 & 8,53 \\
\hline D33 & $80 \%: 20 \%$ & $2: 1$ & 7,40 & 12,73 \\
\hline
\end{tabular}

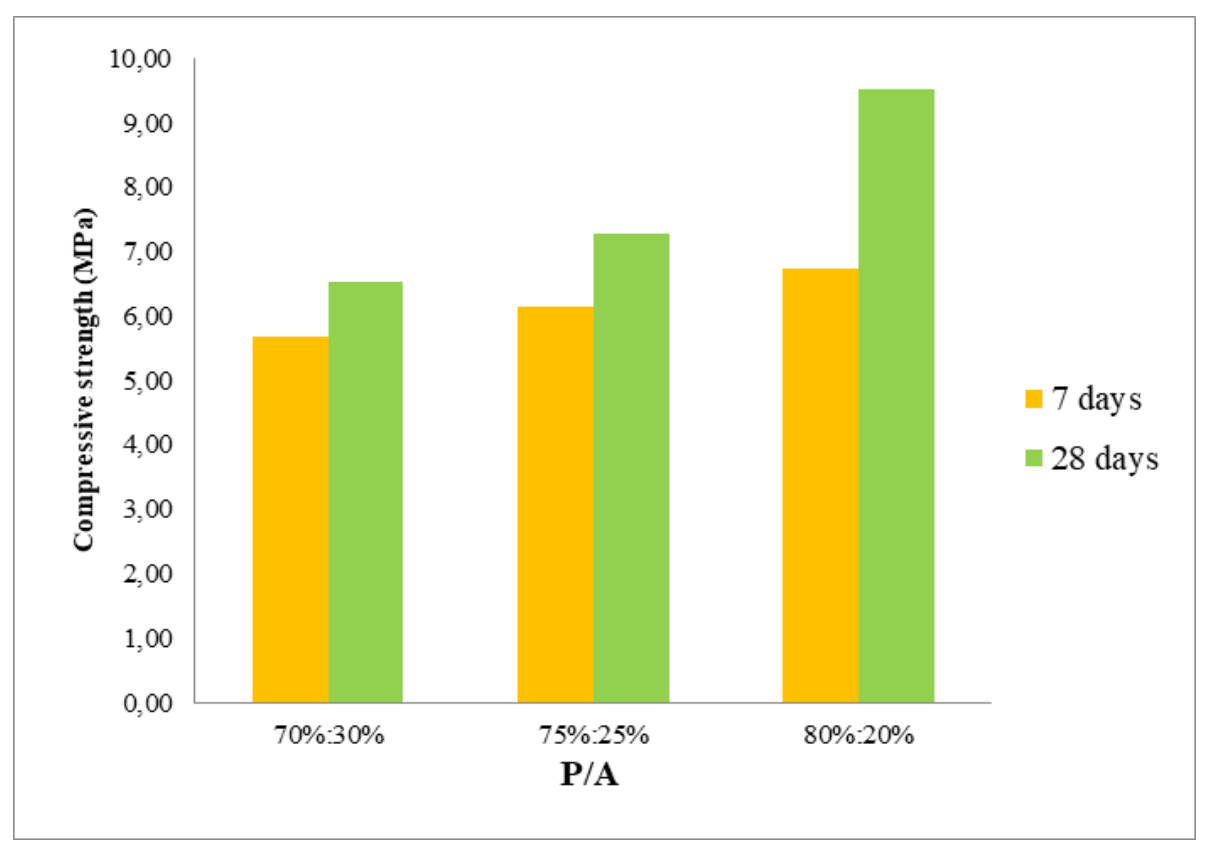

Figure 12. Compressive strength of geopolymer binder $(\mathrm{SS} / \mathrm{SH}=1: 1)$ 


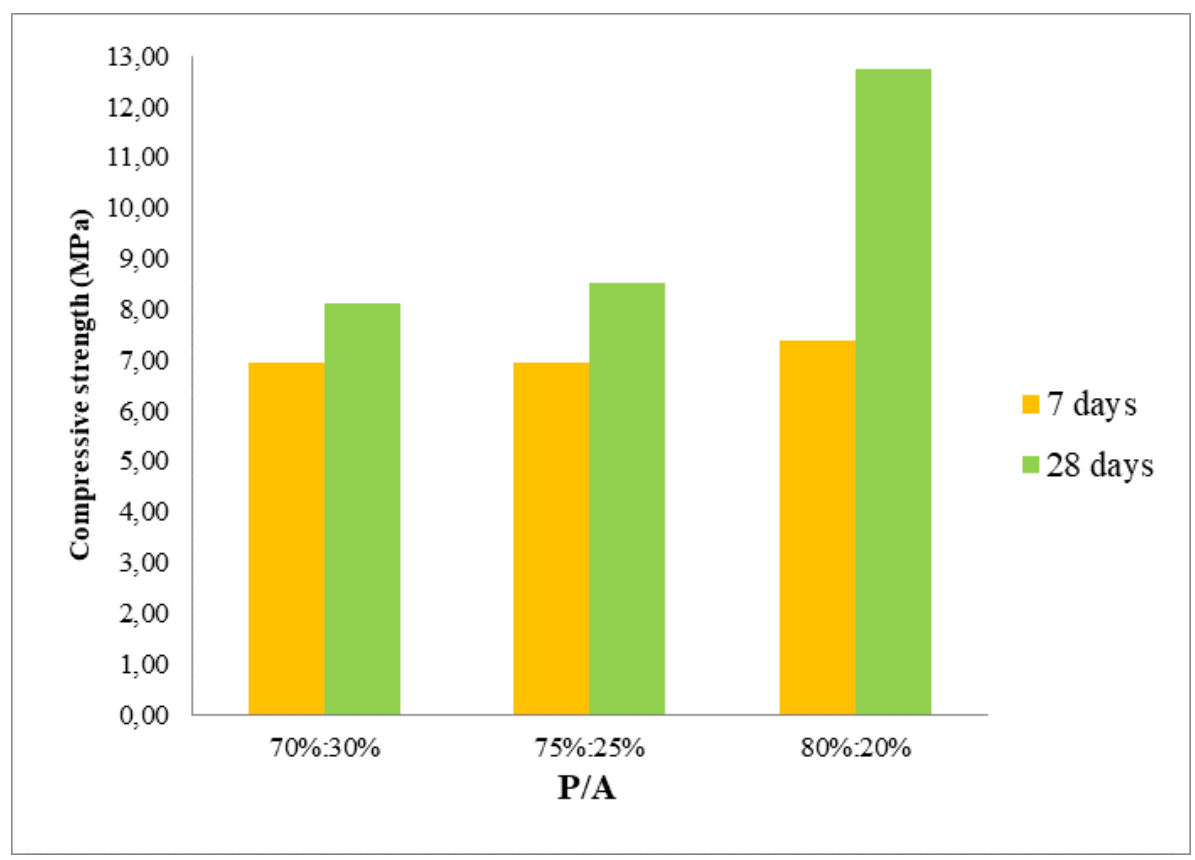

Figure 13. Compressive strength of geopolymer binder ( $\mathrm{SS} / \mathrm{SH}=1,5: 1)$

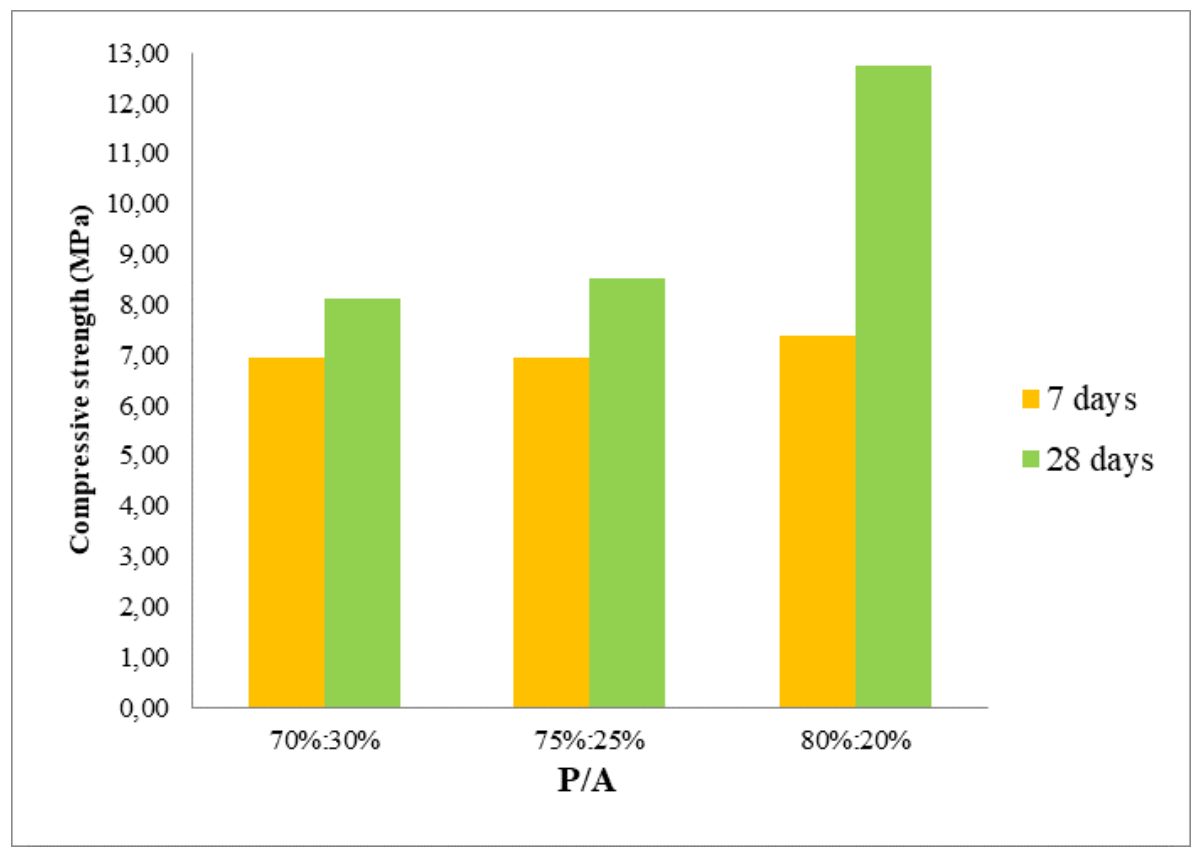

Figure 14. Compressive strength of geopolymer binder $(\mathrm{SS} / \mathrm{SH}=2: 1)$

\subsubsection{Sodium silicate to sodium hydroxide ratio}

The results of the compressive strength produced in each SS/SH variation group are presented in Table 6 and Figure 15-17. There is an increase in the compressive strength value along with the increase in the $\mathrm{SS} / \mathrm{SH}$ ratio and the age of the test. The highest compressive strength was in the $80 \%: 20 \% \mathrm{P} / \mathrm{A}$ group with a $2: 1$ variation of $\mathrm{SS} / \mathrm{SH}$. The alkaline activator with high silicate content can accelerate the geopolymerization process so that it also increases the compressive strength of geopolymer binders [31, 36, 52-54]. The average percentage increase was $18 \%$ in each group. The highest increase in compressive strength occurred in group 3 with a $\mathrm{SS} / \mathrm{SH}$ ratio of $2: 1$. There was an increase in the value of compressive strength up to $30 \%$, which was $12.73 \mathrm{MPa}$. This shows that the presence of sufficient silica in the activator can increase the binder strength so that the geopolymerization process can run more quickly and 
perfectly to produce a higher compressive strength.

Table 6. Compressive strength for SS/SH ratio

\begin{tabular}{|c|c|c|c|}
\hline \multirow{3}{*}{ Group } & Code & 7 days (MPa) & 28 days (MPa) \\
\hline \multirow{3}{*}{1} & D11 & 4,80 & 6,00 \\
\cline { 2 - 4 } & D12 & 5,67 & 6,53 \\
\cline { 2 - 4 } & D13 & 6,93 & 8,13 \\
\hline \multirow{3}{*}{2} & D21 & 5,20 & 6,60 \\
\cline { 2 - 4 } & D22 & 6,13 & 7,27 \\
\cline { 2 - 4 } & D23 & 6,93 & 8,53 \\
\hline \multirow{3}{*}{3} & D31 & 6,07 & 8,07 \\
\cline { 2 - 4 } & D32 & 6,73 & 9,53 \\
\cline { 2 - 4 } & D33 & 7,40 & 12,73 \\
\hline
\end{tabular}

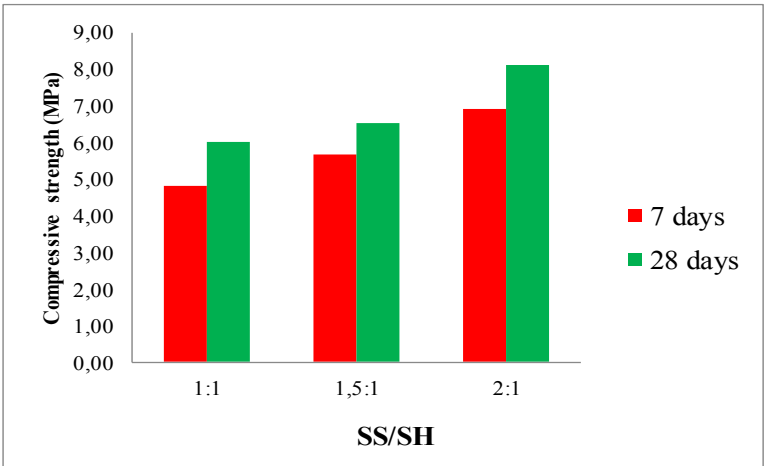

Figure 15. Compressive strength of $\mathrm{P} / \mathrm{A} 70 \%: 30 \%$

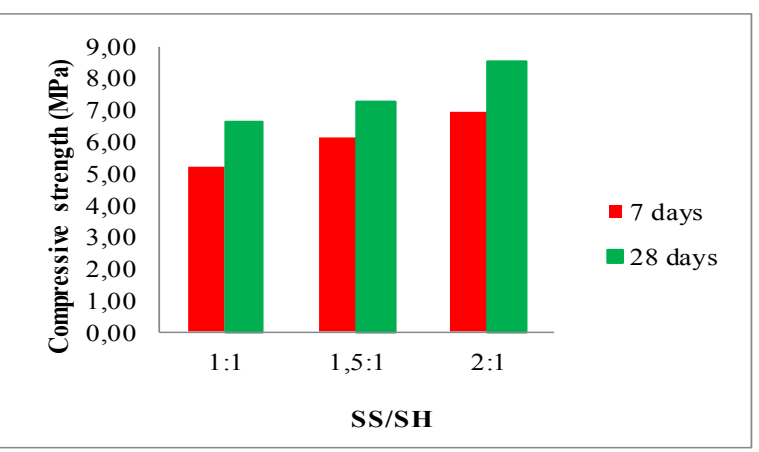

Figure 16. Compressive strength of $\mathrm{P} / \mathrm{A} 75 \%: 25 \%$

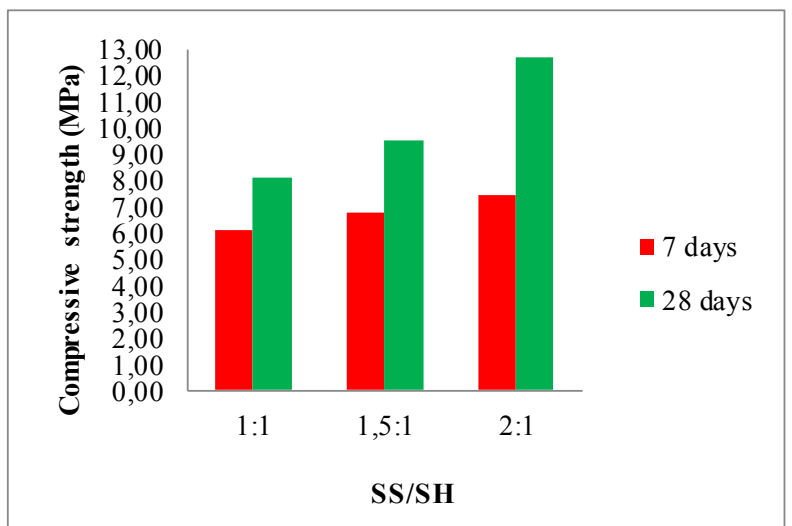

Figure 17. Compressive strength of $\mathrm{P} / \mathrm{A} 80 \%: 20 \%$

\subsection{XRD (X-Ray Diffraction)}

The XRD test process with analysis was carried out after the compressive strength test of the geopolymer binder test object. Figure 18 shows the sample refining process for material characterization according to the XRD test requirements.
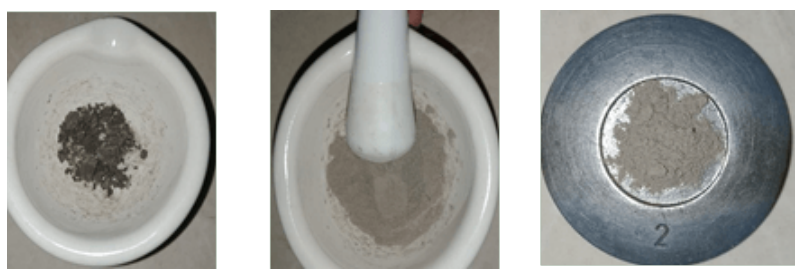

(Source: Lab. Malang, 2021)

Figure 18. Processing of XRD

The results of the XRD analysis can be shown in Figure 19-23 and Table 7-11. Umeanyar slatestone powder has an XRD graph as shown in Figure 19. The results of XRD analysis on USSP precursors with primary mineral content are shown in Table 7. The highest peak of $2 \theta$ between $20^{\circ}-30^{\circ}$ indicates the highest mineral content in USSP powder. Each sample was tested at the age of 7 and 28 days by taking samples with the lowest and highest compressive strength values. 


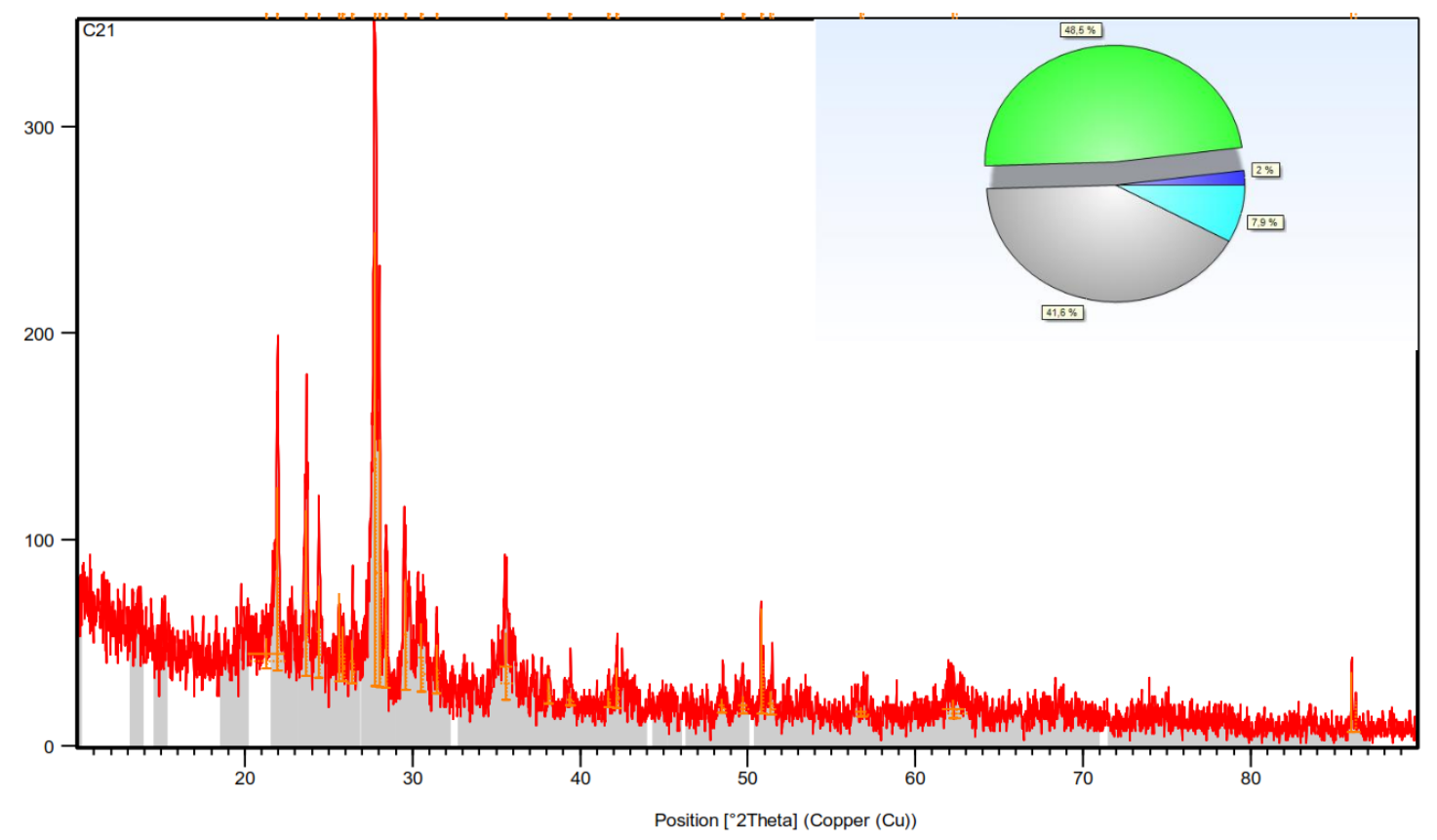

Figure 19. XRD of Umeanyar slatestone powder (USSP)

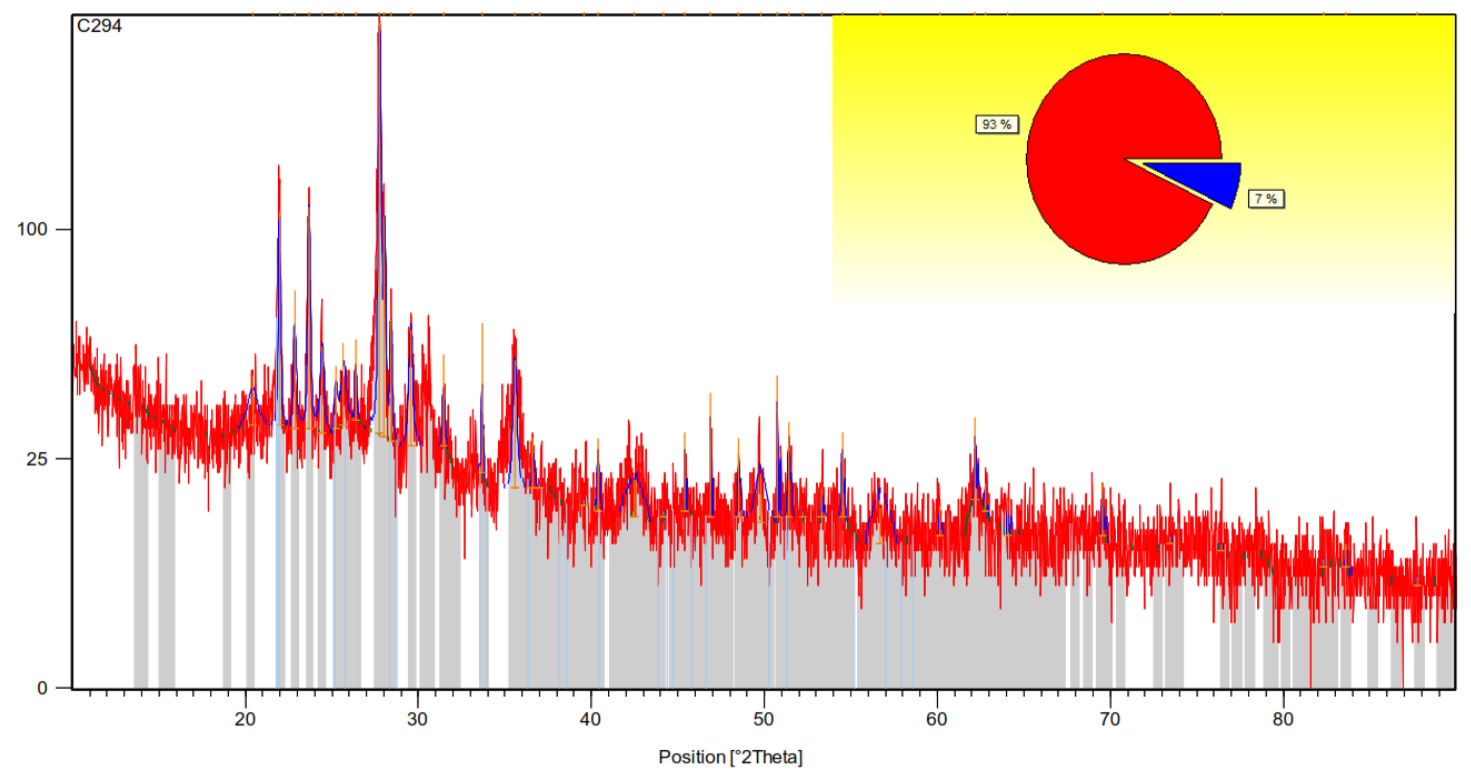

Figure 20. XRD of sample Y11 (7 days)

Table 7. XRD analysis of USSP

\begin{tabular}{|c|c|c|}
\hline Compound name & $\begin{array}{c}\text { Perc. } \\
\text { (\%) }\end{array}$ & Chemical formula \\
\hline Silicon oxide & 2 & $\mathrm{SiO}_{2}$ \\
\hline Iron oxide & 48,5 & $\mathrm{Fe}_{2} \mathrm{O}_{3}$ \\
\hline $\begin{array}{c}\text { Calcium aluminum } \\
\text { silicate }\end{array}$ & 41,6 & $\mathrm{CaAl}_{2} \mathrm{Si}_{2} \mathrm{O}_{8}$ \\
\hline $\begin{array}{c}\text { Potassium hydrogen } \\
\text { titanium oxide hydrate }\end{array}$ & 7,9 & $\mathrm{~K}_{0.48} \mathrm{H}_{0.22} \mathrm{Ti}_{1,825} \mathrm{O} 4(\mathrm{H} 2 \mathrm{O})_{0.52}$ \\
\hline
\end{tabular}

In sample $\mathrm{Y} 11$ at 7 days old, the mineral content of cristobalite was $7 \%$ and albite $93 \%$, this mineral content increased at 28 days by $11 \%$ and $89 \%$, respectively. While the sample Y33 at the age of 7 days has a mineral content of
$9 \%$ cristobalite and $91 \%$ albite, and an increase of $14 \%$ and $86 \%$ respectively at the age of 28 days. Test the sample with an angle of $2 \theta$ from $0^{\circ}-90^{\circ}$. The diffraction peaks showing the binder structure of the USSP geopolymer can be seen in the range of $20^{\circ}-30^{\circ}$. X-ray diffraction results in the formation of different reaction products in geopolymer binders depending on the ratio of the activator used. Characteristically sharp diffraction peaks indicate the development of the crystalline phase from the partially amorphous phase of the geopolymer binder $[41,55]$. The presence of new compounds in the form of cristobalite and albite indicated that the crystalline phase was more dominant than the amorphous phase. The content of 
cristobalite compounds which increased along with the increase in the $\mathrm{P} / \mathrm{A}$ ratio and the $\mathrm{SS} / \mathrm{SH}$ ratio showed that at the age of 28 days the geopolymer binder had a higher amorphous phase than when the specimen was 7 days old. $[56,57]$.
Table 8. XRD analysis of sample Y11 (7 days)

\begin{tabular}{|c|c|c|}
\hline Compound name & Percentage (\%) & Chemical formula \\
\hline Cristobalite & 7 & $\mathrm{SiO}_{2}$ \\
\hline Albite & 93 & $\mathrm{Na}\left(\mathrm{AlSi}_{3} \mathrm{O}_{8}\right)$ \\
\hline
\end{tabular}

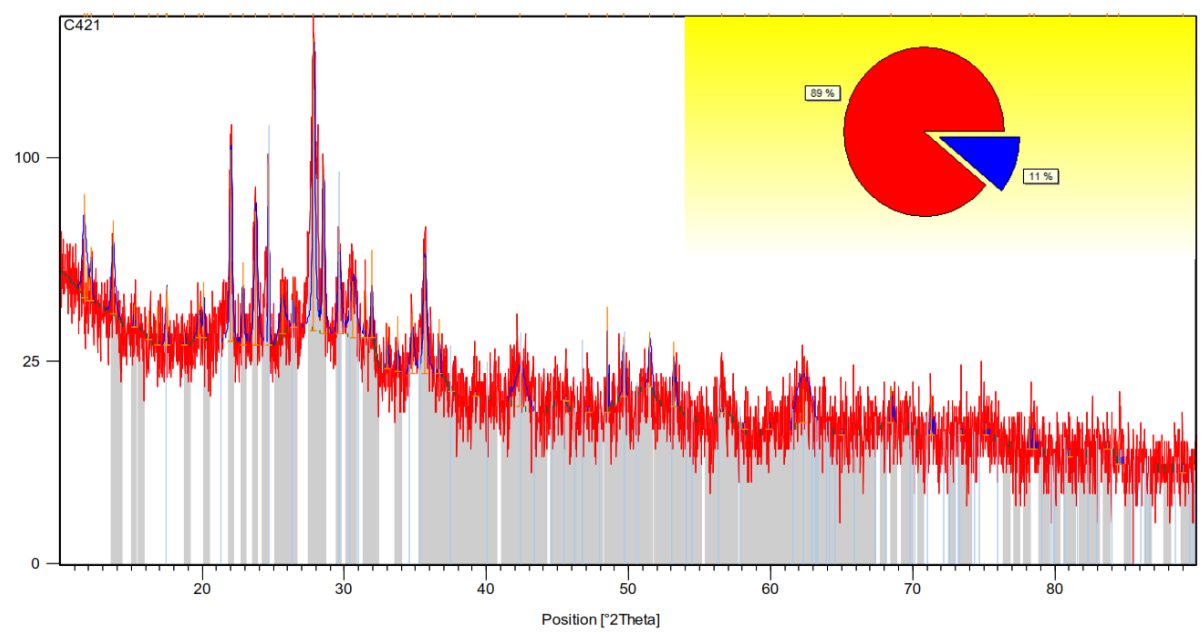

Figure 21. XRD of sample Y11 (28 days)

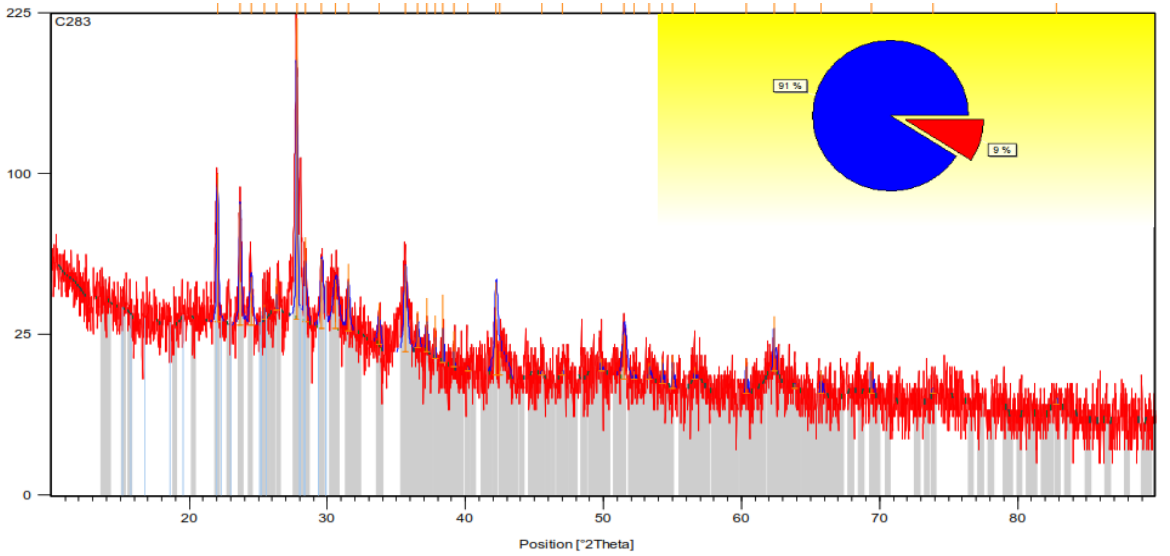

Figure 22. XRD of sample Y33 (7 days)

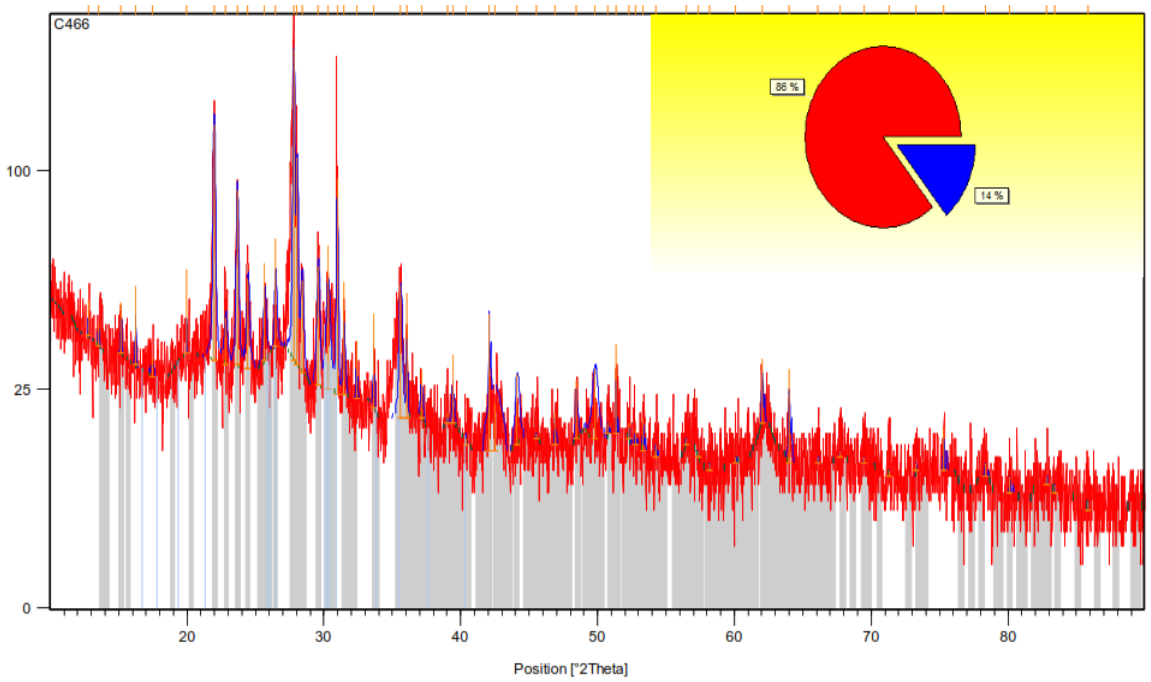

Figure 23. XRD of sample Y33 (28 days) 
Table 9. XRD analysis of sample Y11 (28 days)

\begin{tabular}{|c|c|c|}
\hline Compound name & Percentage (\%) & Chemical formula \\
\hline Cristobalite & 11 & $\mathrm{SiO}_{2}$ \\
\hline Albite & 89 & $\mathrm{Na}\left(\mathrm{AlSi}_{3} \mathrm{O}_{8}\right)$ \\
\hline
\end{tabular}

Table 10. XRD analysis of sample Y33 (7 days)

\begin{tabular}{|c|c|c|}
\hline Compound name & Percentage (\%) & Chemical formula \\
\hline Cristobalite & 9 & $\mathrm{SiO}_{2}$ \\
\hline Albite & 91 & $\mathrm{Na}\left(\mathrm{AlSi}_{3} \mathrm{O}_{8}\right)$ \\
\hline
\end{tabular}

Table 11. XRD analysis of sample Y33 (28 days)

\begin{tabular}{|c|c|c|}
\hline Compound name & Percentage (\%) & Chemical formula \\
\hline Cristobalite & 14 & $\mathrm{SiO} 2$ \\
\hline Albite & 86 & $\mathrm{Na}\left(\mathrm{AlSi}_{3} \mathrm{O}_{8}\right)$ \\
\hline
\end{tabular}

\subsection{SEM (Scanning Electronic Microscope)}

The SEM-EDX test was carried out on specimens with variations in age of 7 and 28 days with the lowest and highest ratios of $\mathrm{P} / \mathrm{A}$ and $\mathrm{SS} / \mathrm{SH}$. The results of the SEM-EDX test for USSP precursors are shown in Figures 24-25 and Table 12. The results of the analysis show that USSP has a microstructure with the $\mathrm{K}$ electron shell having the highest $\mathrm{OK}$ content followed by $\mathrm{SiK}, \mathrm{CK}, \mathrm{AlK}$ and several other compounds with a small percentage.

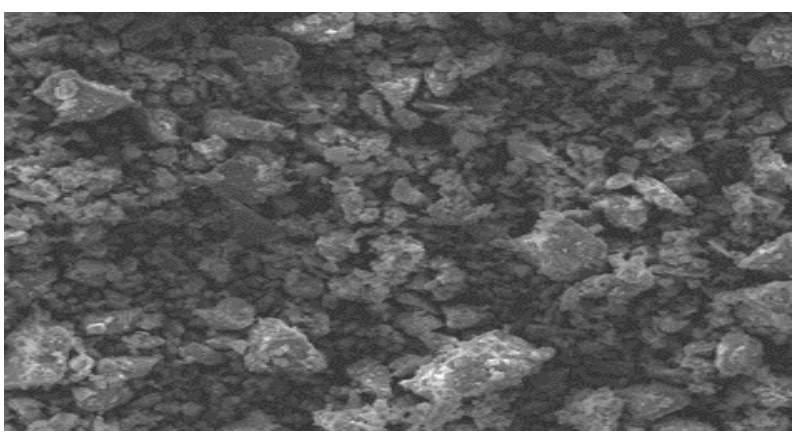

(Source: Lab. Malang, 2021)

Figure 24. SEM test of USSP

Table 12. SEM analysis of USSP

\begin{tabular}{|c|c|c|}
\hline Element & Wt\% & At\% \\
\hline $\mathrm{CK}$ & 09.05 & 15.00 \\
\hline $\mathrm{OK}$ & 43.80 & 54.49 \\
\hline $\mathrm{NaK}$ & 01.91 & 01.65 \\
\hline $\mathrm{AlK}$ & 08.70 & 06.42 \\
\hline $\mathrm{SiK}$ & 24.05 & 17.04 \\
\hline $\mathrm{KK}$ & 01.92 & 00.98 \\
\hline $\mathrm{CaK}$ & 04.64 & 02.31 \\
\hline FeK & 05.94 & 02.12 \\
\hline Matrix & Correction & ZAF \\
\hline
\end{tabular}

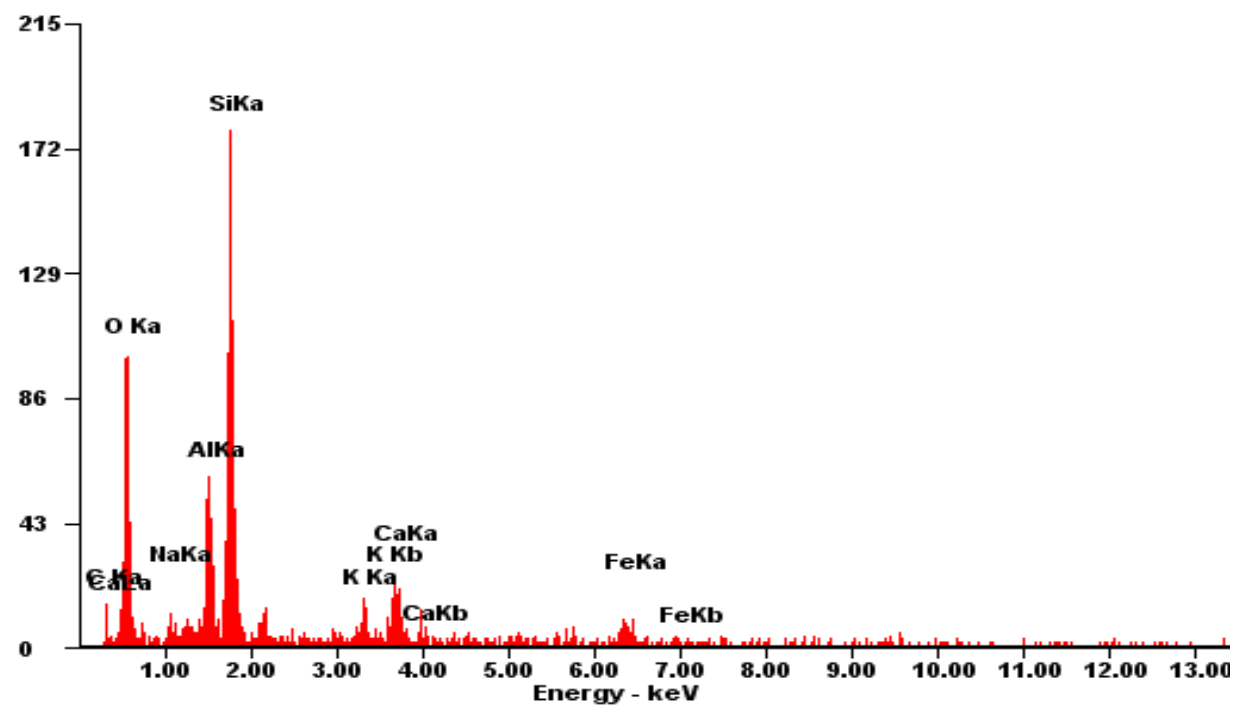

Figure 25. Microanalysis of USSP 


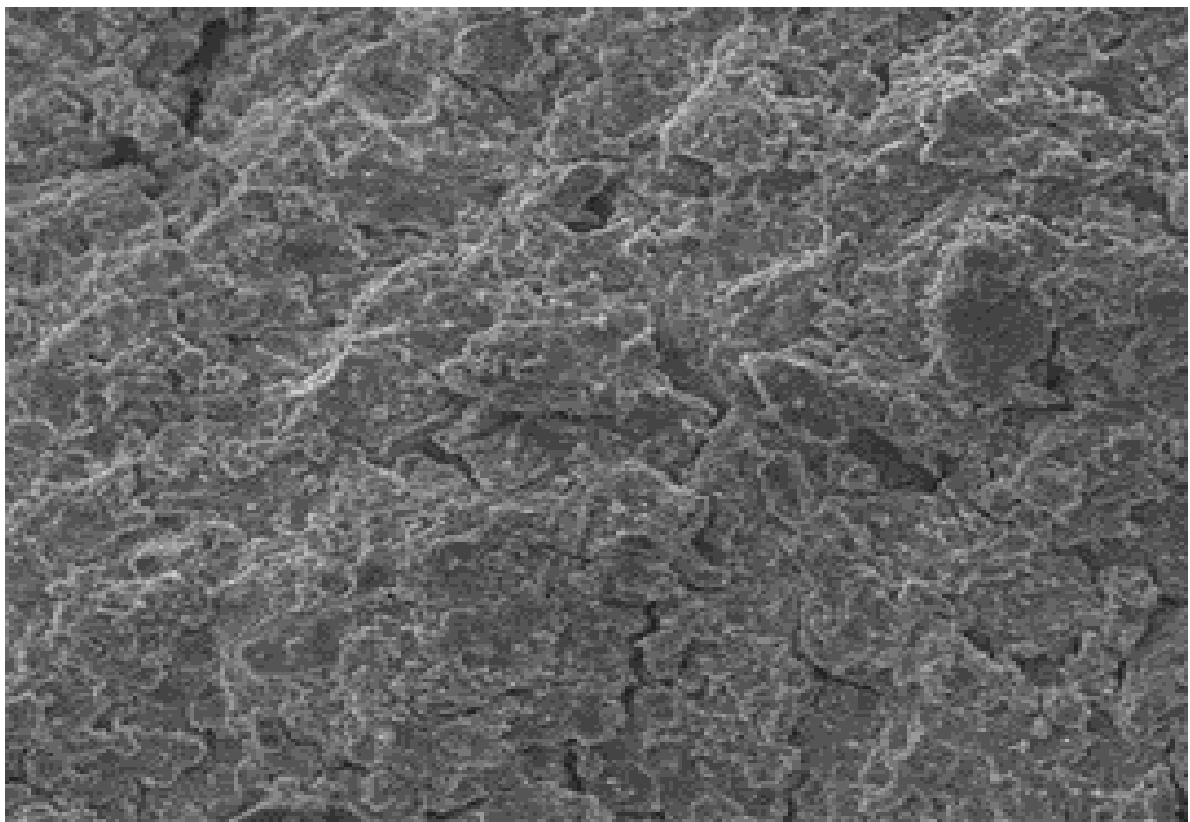

(Source: Lab. Malang, 2021)

Figure 26. SEM test of sample Y11 (7 days)

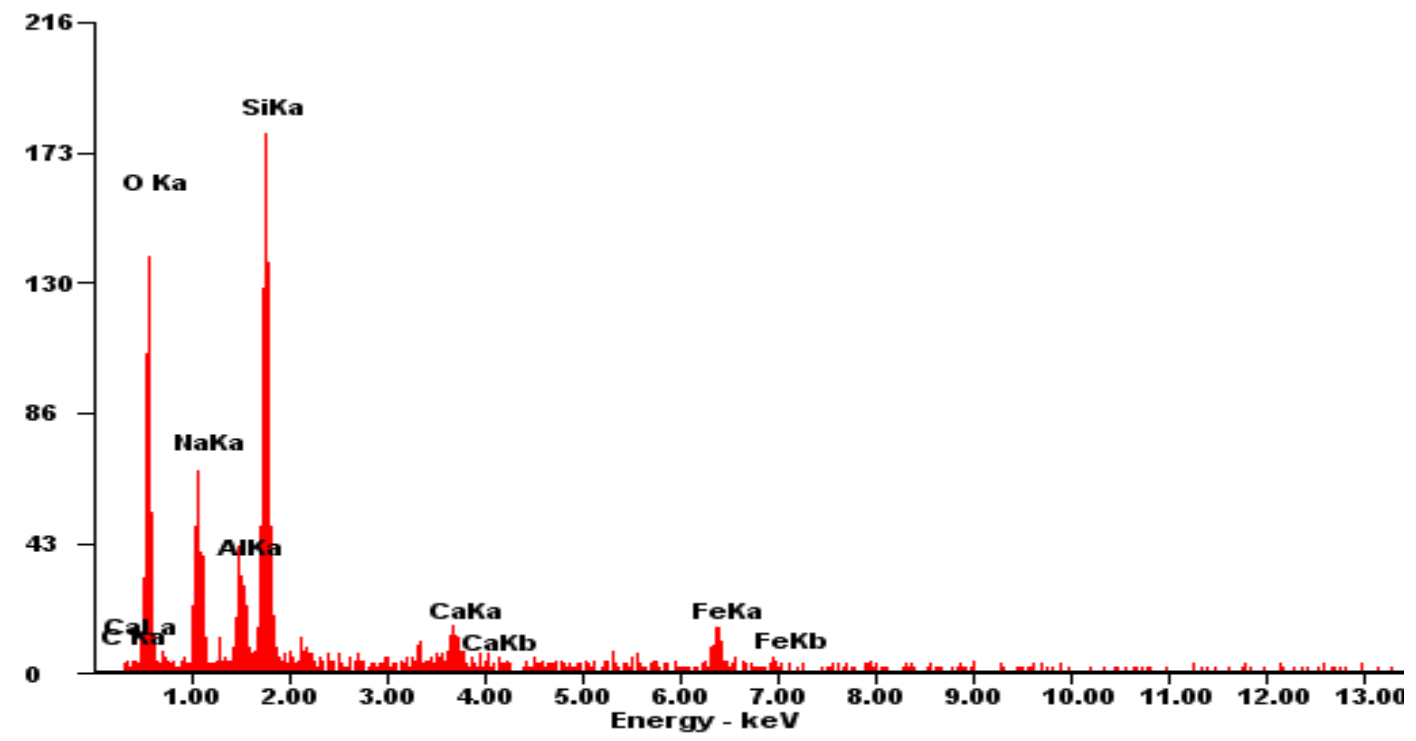

Figure 27. Microanalysis of Y11 (7 days) 
Table 13. SEM analysis of sample Y11 (7 days)

\begin{tabular}{|c|c|c|}
\hline Element & $\mathrm{Wt} \%$ & $\mathrm{At} \%$ \\
\hline $\mathrm{CK}$ & 08,14 & 13,41 \\
\hline $\mathrm{OK}$ & 41,92 & 51,82 \\
\hline $\mathrm{NaK}$ & 13,05 & 11,22 \\
\hline $\mathrm{MgK}$ & 00,58 & 00,47 \\
\hline $\mathrm{AlK}$ & 05,79 & 04,25 \\
\hline $\mathrm{SiK}$ & 21,04 & 14,81 \\
\hline $\mathrm{KK}$ & 01,67 & 00,85 \\
\hline $\mathrm{CaK}$ & 02,94 & 01,45 \\
\hline FeK & 04,87 & 01,72 \\
\hline Matrix & Correction & ZAF \\
\hline
\end{tabular}

When sample Y11 was 7 days old, a new compound appeared, namely $\mathrm{MgK}$, but the value was small, namely $0.58 \%$. There was an increase in $\mathrm{SiK}$ content by $23.68 \%$ at the age of 28 days. This shows that increasing the age and the SS/SH ratio can increase the silica content of the geopolymer binder. This also happened in studies using fly ash precursors [29, 49, 58-62]. Samples with the highest compressive strength values were also tested by SEM-EDX, the results are shown in Figures 30-33 and Tables 15-16. The content of MgK compounds also appeared in sample Y33 (28 days) which was $1.62 \%$, this value was greater than the variation of $\mathrm{Y} 11$. SiK content is also higher up to $23.92 \%$. With the increase in silica content that has been activated with alkaline activator, it can help the polymerization reaction that occurs in geopolymer binder. Binder with high silica and alumina content are factors that can increase compressive strength. Samples with a high $\mathrm{SS} / \mathrm{SH}$ activator ratio also affected the presence of $\mathrm{MgK}$ and $\mathrm{SiK}$, so that the resulting compressive strength was higher.

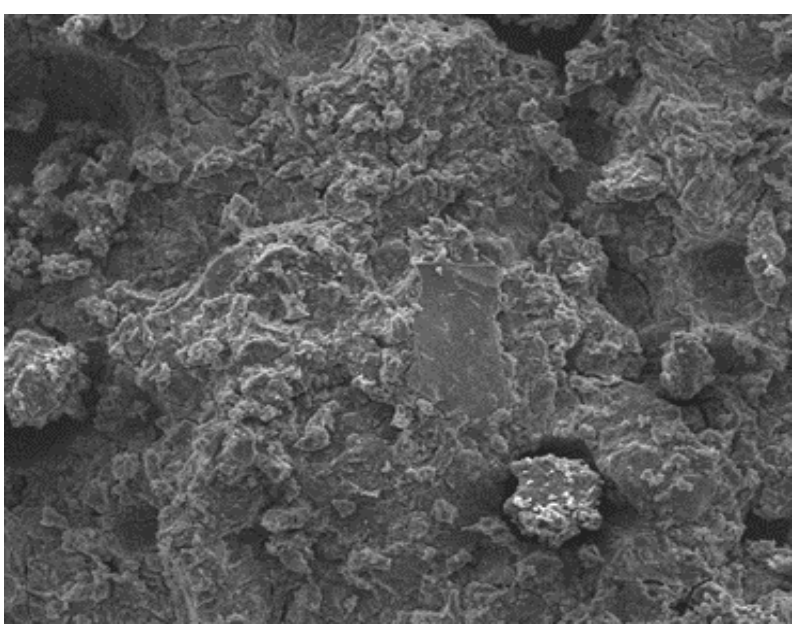

(Source: Lab. Malang, 2021)

Figure 28. SEM test of sample Y11 (28 days)

Table 14. SEM analysis of sample Y11 (28 days)

\begin{tabular}{|c|c|c|}
\hline Element & Wt\% & At\% \\
\hline $\mathrm{CK}$ & 03.80 & 06,43 \\
\hline $\mathrm{OK}$ & 44,13 & 56,10 \\
\hline $\mathrm{NaK}$ & 13,98 & 12,36 \\
\hline $\mathrm{AlK}$ & 05,79 & 04,36 \\
\hline $\mathrm{SiK}$ & 23,68 & 17,15 \\
\hline $\mathrm{CaK}$ & 03,17 & 01,61 \\
\hline FeK & 05,45 & 01,98 \\
\hline Matrix & Correction & $\mathrm{ZAF}$ \\
\hline
\end{tabular}

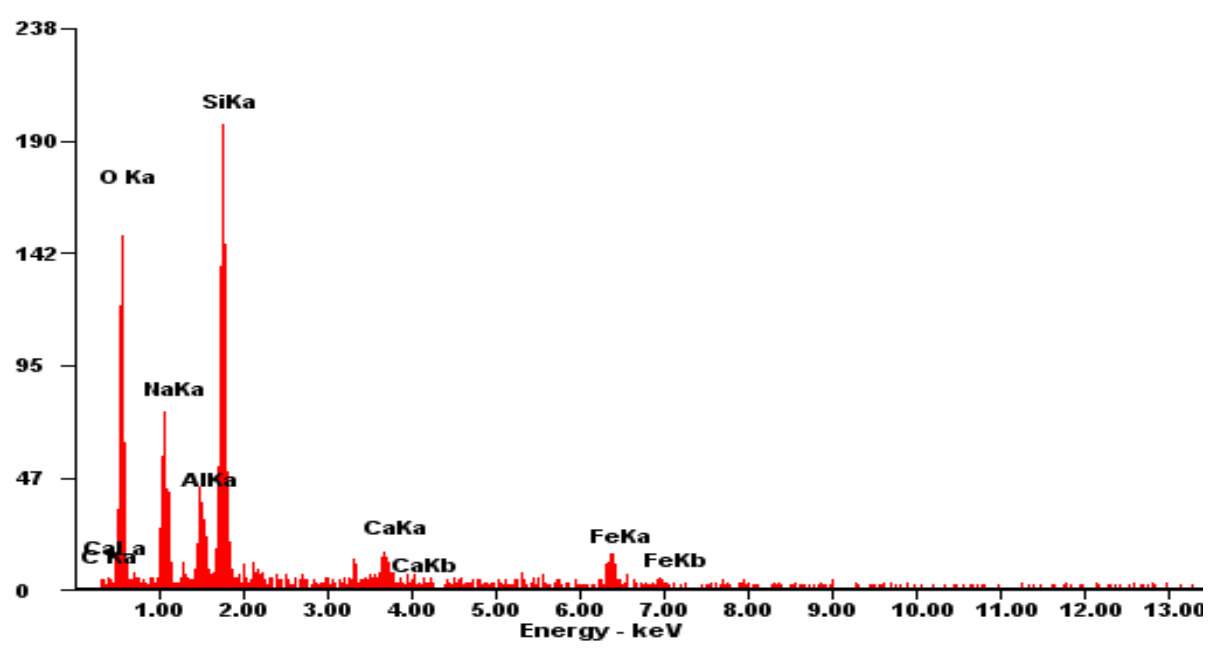

Figure 29. Microanalysis of Y11 (28 days) 


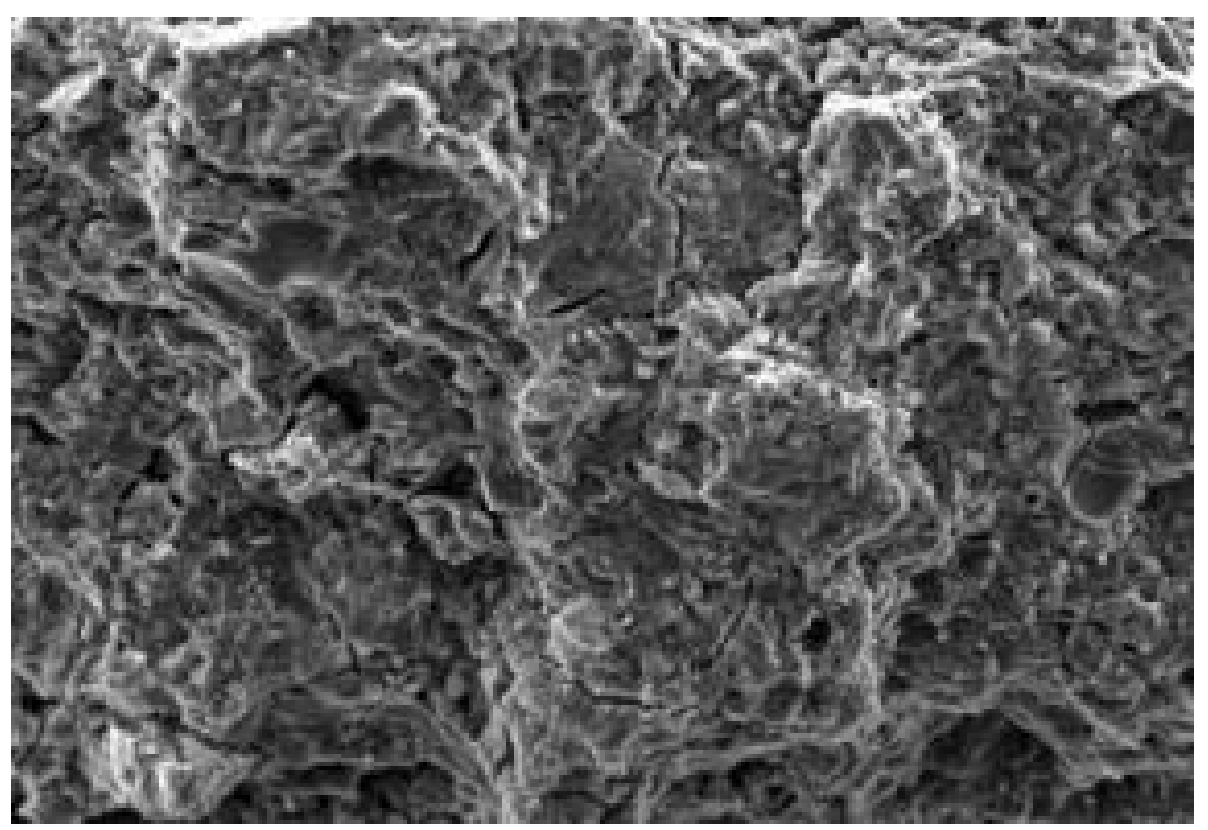

(Source: Lab. Malang, 2021)

Figure 30. SEM test of sample Y33 (7 days)

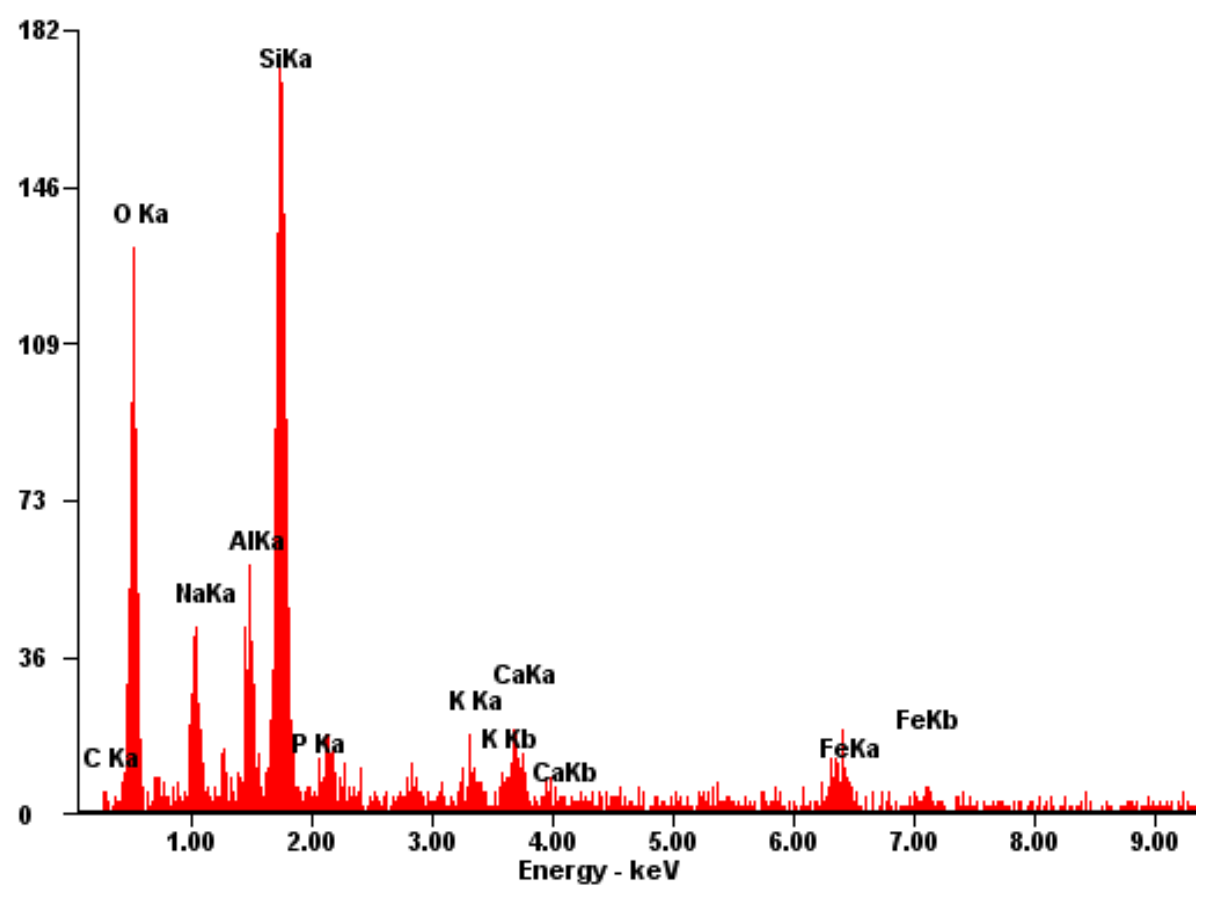

Figure 31. Microanalysis of Y33 (7 days) 
Table 15. SEM analysis of sample Y33 (7 days)

\begin{tabular}{|c|c|c|}
\hline Element & Wt\% & At\% \\
\hline CK & 08,13 & 13,53 \\
\hline OK & 42,26 & 52,81 \\
\hline NaK & 08,74 & 07,60 \\
\hline AlK & 06,87 & 05,09 \\
\hline SiK & 23,03 & 16,39 \\
\hline PK & 00,33 & 00,21 \\
\hline KK & 01,29 & 00,66 \\
\hline CaK & 02,48 & 01,23 \\
\hline FeK & 06,87 & 02,46 \\
\hline Matrix & Correction & ZAF \\
\hline
\end{tabular}

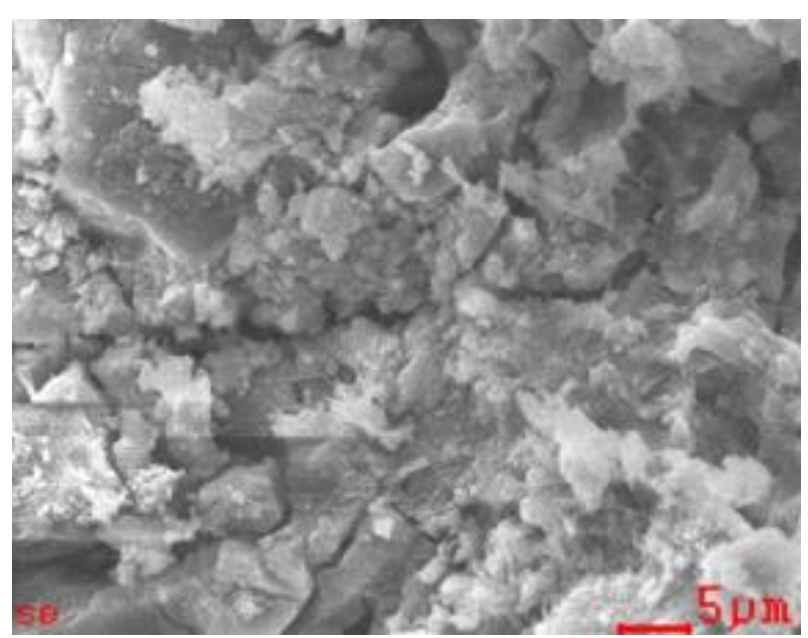

(Source: Lab. Malang, 2021)

Figure 32. SEM test of sample Y33 (28 days)

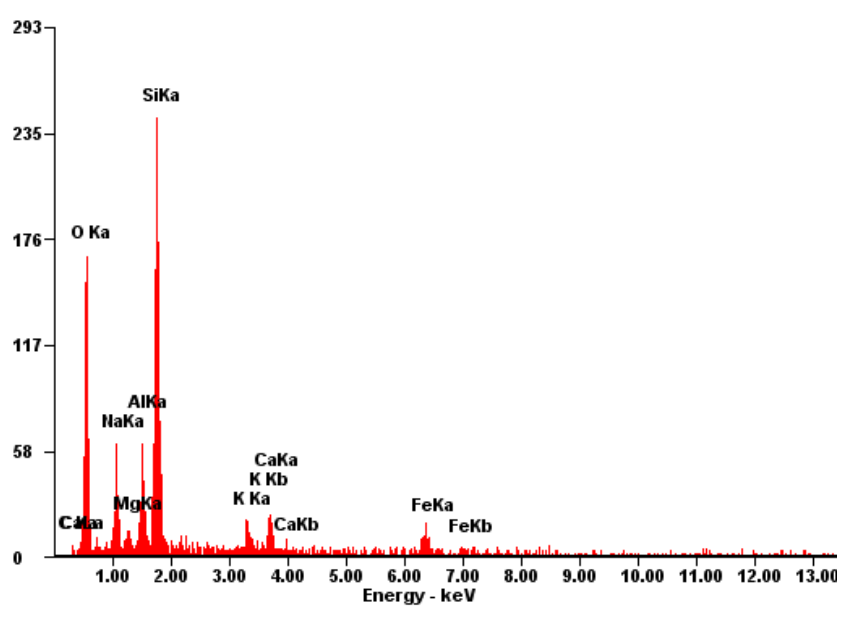

Figure 33. Microanalysis of Y33 (28 days)
Table 16. SEM analysis of sample Y33 (28 days)

\begin{tabular}{|c|c|c|}
\hline Element & $\mathbf{W t} \%$ & At\% \\
\hline $\mathrm{CK}$ & 02,95 & 05,05 \\
\hline $\mathrm{OK}$ & 45,55 & 58,48 \\
\hline $\mathrm{NaK}$ & 08,66 & 07,73 \\
\hline $\mathrm{MgK}$ & 01,62 & 01,37 \\
\hline $\mathrm{AlK}$ & 06,89 & 05,25 \\
\hline $\mathrm{SiK}$ & 23,92 & 17,49 \\
\hline $\mathrm{KK}$ & 01,90 & 01,00 \\
\hline $\mathrm{CaK}$ & 03,47 & 01,78 \\
\hline FeK & 05,05 & 01,86 \\
\hline Matrix & Correction & ZAF \\
\hline
\end{tabular}

\section{Conclusions}

This research resulted in several things related to the mechanical properties and microstructure of geopolymer binders based on Umeanyar slatestone powder (USSP), namely:

- The density test which affects the physical properties of the geopolymer binder is influenced by the ratio of $\mathrm{P} / \mathrm{A}$ and $\mathrm{SS} / \mathrm{SH}$ as well as age at the time of testing. The higher the ratio of $\mathrm{P} / \mathrm{A}, \mathrm{SS} / \mathrm{SH}$, and age, the higher the density value

- The compressive strength test was carried out at the age of 7 and 28 days, giving the highest results at the age of 28 days with the highest ratio of $\mathrm{P} / \mathrm{A}(80 \%: 20 \%)$ and SS/SH (2:1)

- Microstructural testing was carried out using XRD and SEM-EDX analysis. XRD analysis was carried out to determine the diffraction peaks of the crystalline and amorphous phases of the compounds formed. Meanwhile, the SEM-EDX test was conducted to determine the surface shape of the USSP-based binder sample. The result is that a new compound is formed, namely $\mathrm{Mg}$ in the binder, in addition to the Si content which is formed more and more after 28 days of age with the highest compressive strength.

\section{Acknowledgments}

We are very grateful to the Ngurah Rai University, Udayana University, and Malang University for their appropriate and constructive suggestions to support the data of this study. 


\section{REFERENCES}

[1] T. Mulyono, Teknologi Beton. Yogyakarta: Andi Offset, 2004.

[2] T. Wajima and S. Buntan, "Conversion of Waste Stone-Fine Slurry into Geopolymer Cement with Addition of Coal FLY ASH," Int. J. GEOMATE, vol. 20, no. 78, pp. 44-49, 2021, doi: 10.21660/2021.78.Gx133.

[3] H. A. Mboya, K. N. Njau, A. L. Mrema, and C. K. King'ondu, "Influence of scoria and pumice on key performance indicators of Portland cement concrete," Constr. Build. Mater., vol. 197, pp. 444-453, 2019, doi: 10.1016/j.conbuildmat.2018.11.228.

[4] Z. Dakhli, K. Chaffar, and Z. Lafhaj, "The Effect of Phase Change Materials on the Physical, Thermal and Mechanical Properties of Cement," Sci, vol. 1, no. 1, p. 27, 2019, doi: $10.3390 /$ sci1010027.

[5] A. Naghizadeh and S. O. Ekolu, "Pozzolanic Materials and Waste Products for Formulation of Geopolymer Cements in Developing Countries : a Review," Concr. Bet., vol. 151, no. 151, pp. 22-31, 2017.

[6] A. A. Bello, J. A. Ige, and G. I. Ibitoye, "Geotechnical properties of lateritic soils stabilized with cement-bamboo leaf ash admixtures," Int. J. Appl. Eng. Res., vol. 9, no. 21, pp. 9655-9666, 2014.

[7] K. Sakamoto, "Preparation of Geopolymer Cement From Simulated Lunar Rock Sand Using Alkali Fusion," Int. J. GEOMATE, vol. 18, no. 70, pp. 62-67, 2020, doi: $10.21660 / 2020.70 .9162$

[8] A. RIZK, E. KISHAR, D. AHMED, and M. KOHAIL, "Preparation and Characterization of Low Cost Geopolymer Cement," J. Sci. Res. Sci., vol. 36, no. 1, pp. 36-48, 2019, doi: 10.21608/jsrs.2019.30996.

[9] I. Rustendi, E. Poerwodihardjo, and C. P. Hudoyo, "Utilization of iron sand waste and bottom ash as alternate concrete-making materials," Civil Engineering and Architecture, vol. 8, no. 4, pp. 549-556, 2020, doi: 10.13189/cea.2020.080419.

[10] L. D. Ellis, A. F. Badel, M. L. Chiang, R. J.-Y. Park, and Y.-M. Chiang, " Toward electrochemical synthesis of cement-An electrolyzer-based process for decarbonating CaCO 3 while producing useful gas streams ," Proc. Natl. Acad. Sci., p. 201821673, 2019, doi: $10.1073 /$ pnas. 1821673116 .

[11] Https://www.statista.com/statistics/219343/cement-product ion-worldwide/, Cement production in the United States and worldwide from 2010 to 2020 .

[12] R. M. Andrew, "Global $\mathrm{CO}_{2}$ emissions from cement production,” Earth Syst. Sci. Data, no. September, pp. 1-52, 2017.

[13] J. Davidovits, "Properties of Geopolymer Cements," First Int. Conf. Alkaline Cem. Concr., no. October 1994, pp. 131$149,1994$.

[14] J. Davidovits, Geopolymer Chemistry and Applications 3 rd edition, no. January 2008. 2008.

[15] J. Davidovits, Geopolymer. 2015.

[16] J. Davidovits, "Geopolymers," J. Therm. Anal., vol. 37, no. 8, pp. 1633-1656, 1991, doi: 10.1007/bf01912193.

[17] J. Davidovits, "Geopolymer Cement a review," Inst. Geopolymer, no. 0, pp. 1-11, 2013.

[18] N. B. Singh, "Fly ash-based geopolymer binder: A future construction material," Minerals, vol. 8, no. 7, 2018, doi: $10.3390 / \min 8070299$.

[19] D. Hardjito and B. V Rangan, "Development and Properties of Low-calcium Fly Ash Based Geopolymer LOW-CALCIUM FLY ASH-BASED GEOPOLYMER CONCRETE By Faculty of Engineering Curtin University of Technology," no. January, p. 48, 2005.

[20] V. Siriphongphanh, P. Aengchuan, and A. Poowancum, "Design of experiment of geopolymer from metakaolin blended with fly ash," Suranaree J. Sci. Technol., vol. 26, no. 3, pp. 278-283, 2019.

[21] S. Ukritnukun, P. Koshy, A. Rawal, A. Castel, and C. C. Sorrell, "Predictive model of setting times and compressive strengths for low-alkali, ambient-cured, fly ash/slag-based geopolymers," Minerals, vol. 10, no. 10, pp. 1-21, 2020, doi: $10.3390 / \min 10100920$.

[22] S. Samantasinghar and S. P. Singh, "Fresh and Hardened Properties of Fly Ash-Slag Blended Geopolymer Paste and Mortar," Int. J. Concr. Struct. Mater., vol. 13, no. 1, pp. 112, 2019, doi: 10.1186/s40069-019-0360-1.

[23] I. W. Karyasa, "Pengembangan Cementious Binder Dari Limbah Batu Pipih , Silika Abu Sekam Padi Dan Batu Gamping Serta Pemanfaatannya Dalam Pembuatan," in Seminar Nasional FMIPA UNDIKSA III, 2013, no. July, pp. 178-184.

[24] V. Cárdenes, M. Ponce de León, X. A. Rodríguez, and A. Rubio-Ordoñez, "Roofing Slate Industry in Spain: History, Geology, and Geoheritage," Geoheritage, vol. 11, no. 1, pp. 19-34, 2019, doi: 10.1007/s12371-017-0263-y.

[25] I. W. Karyasa, "Studi X-Ray Fluoresence Dan X-Ray Diffraction Terhadap Bidang Belah Batu Pipih Asal Tejakula," JST (Jurnal Sains dan Teknol., vol. 2, no. 2, 2014, doi: 10.23887/jst-undiksha.v2i2.2895.

[26] C. Leonelli and M. Romagnoli, Rheology parameters of alkali-activated geopolymeric concrete binders. Woodhead Publishing Limited, 2015.

[27] A. Leonard Wijaya, J. Jaya Ekaputri, and Triwulan, "Factors influencing strength and setting time of fly ash based-geopolymer paste," MATEC Web Conf., vol. 138, 2017, doi: $10.1051 /$ matecconf/201713801010.

[28] H. Binici, "Engineering properties of geopolymer incorporating slag, fly ash, silica sand and pumice," $A d v$. Civ. Environ. Eng., vol. 01, no. 3, pp. 108-123, 2013.

[29] X. Li, X. Ma, S. Zhang, and E. Zheng, "Mechanical properties and microstructure of class $\mathrm{C}$ fly ash-based geopolymer paste and mortar," Materials (Basel)., vol. 6, no. 4, pp. 1485-1495, 2013, doi: 10.3390/ma6041485.

[30] O. Peyronnard and M. Benzaazoua, "Alternative 
by-product based binders for cemented mine backfill: Recipes optimisation using Taguchi method," Miner. Eng., vol. 29, pp. 28-38, 2012, doi: 10.1016/j.mineng.2011.12.010.

[31] P. Risdanareni, J. J. Ekaputri, and M. M. Al Bakri Abdullah, "Effect of Alkaline Activator Ratio to Mechanical Properties of Geopolymer Concrete with Trass as Filler," Appl. Mech. Mater., vol. 754-755, no. April, pp. 406-412, 2015, doi: 10.4028/www.scientific.net/amm.754-755.406.

[32] C. Ruiz-Santaquiteria, J. Skibsted, A. Fernández-Jiménez, and A. Palomo, "Alkaline solution/binder ratio as a determining factor in the alkaline activation of aluminosilicates," Cem. Concr. Res., vol. 42, no. 9, pp. 1242-1251, 2012, doi: 10.1016/j.cemconres.2012.05.019.

[33] M. O. Yusuf, M. A. Megat Johari, Z. A. Ahmad, and M. Maslehuddin, "Effects of $\mathrm{H} 2 \mathrm{O} / \mathrm{Na} 2 \mathrm{O}$ molar ratio on the strength of alkaline activated ground blast furnace slag-ultrafine palm oil fuel ash based concrete," Mater. Des., vol. 56, pp. 158-164, 2014, doi: 10.1016/j.matdes.2013.09.078.

[34] G. S. Ryu, Y. B. Lee, K. T. Koh, and Y. S. Chung, "The mechanical properties of fly ash-based geopolymer concrete with alkaline activators," Constr. Build. Mater., vol. 47, no. 2013, pp. 409-418, 2013, doi: 10.1016/j.conbuildmat.2013.05.069.

[35] M. Dineshkumar and C. Umarani, "Effect of Alkali Activator on the Standard Consistency and Setting Times of Fly Ash and GGBS-Based Sustainable Geopolymer Pastes," $A d v$. Civ. Eng., vol. 2020, 2020, doi: $10.1155 / 2020 / 2593207$.

[36] Nyein Nyein Thant | Zin Mar Soe, "The Effect of Dosage and Modulus of Activator on the Strength of Alkali Activated Slag and Fly Ash Based on Geopolymer Mortar," Int. J. Trend Sci. Res. Dev. Int. J. Trend Sci. Res. Dev., vol. 3, no. 5, pp. 2220-2224, 2019, doi: https://doi.org/10.31142/ijtsrd27997.

[37] SNI 1973:2008, "Cara uji berat isi , volume produksi campuran dan kadar udara beton," Standar Nas. Indones., p. $16,2008$.

[38] K. Sakamoto and T. Wajima, "Preparation of geopolymer cement from crushed stone by-product using alkali fusion," Int. J. GEOMATE, vol. 17 , no. 63, pp. 17-22, 2019, doi: 10.21660/2019.63.4536.

[39] N. Doğan-Sağlamtimur, H. Oznuroz, A. Bilgil, T. Vural, and E. Süzgec, "The effect of alkali activation solutions with different water glass $/ \mathrm{NaOH}$ solution ratios on geopolymer composite materials," IOP Conf. Ser. Mater. Sci. Eng., vol. 660, no. 1, 2019, doi: $10.1088 / 1757-899 X / 660 / 1 / 012003$.

[40] A. B. Malkawi, M. F. Nuruddin, A. Fauzi, H. Almattarneh, and B. S. Mohammed, "Effects of Alkaline Solution on Properties of the HCFA Geopolymer Mortars," Procedia Eng., vol. 148, pp. 710-717, 2016, doi: 10.1016/j.proeng.2016.06.581.

[41] T. Luukkonen, Z. Abdollahnejad, J. Yliniemi, P. Kinnunen, and M. Illikainen, "One-part alkali-activated materials: A review," Cem. Concr. Res., vol. 103, no. November 2017, pp. 21-34, 2018, doi: 10.1016/j.cemconres.2017.10.001.
[42] B. S. Mohammed, S. Haruna, M. M. A. Wahab, M. S. Liew, and A. Haruna, "Mechanical and microstructural properties of high calcium fly ash one-part geopolymer cement made with granular activator," Heliyon, vol. 5, no. 9. 2019, doi: 10.1016/j.heliyon.2019.e02255.

[43] A. H. Mahmood, S. J. Foster, and A. Castel, "Development of high-density geopolymer concrete with steel furnace slag aggregate for coastal protection structures," Constr. Build. Mater., vol. 248, p. 118681, 2020, doi: 10.1016/j.conbuildmat.2020.118681.

[44] ASTM C39, "Compressive Strength of Cylindrical Concrete Specimens," ASTM Stand., pp. 1-7, 2015, doi: 10.1520/C0039.

[45] A. Z. W. Wazien, M. M. A. B. Abdullah, R. Abd Razak, M. A. Z. M. R. Rozainy, and M. F. M. Tahir, "Strength and Density of Geopolymer Mortar Cured at Ambient Temperature for Use as Repair Material," IOP Conf. Ser. Mater. Sci. Eng., vol. 133, no. 1, 2016, doi: 10.1088/1757-899X/133/1/012042.

[46] R. M. Novais, G. Ascensão, M. P. Seabra, and J. A. Labrincha, "Waste glass from end-of-life fluorescent lamps as raw material in geopolymers," Waste Manag., vol. 52, pp. 245-255, 2016, doi: 10.1016/j.wasman.2016.04.003.

[47] Y. Y. Kim, B. J. Lee, V. Saraswathy, and S. J. Kwon, "Strength and durability performance of alkali-activated rice husk ash geopolymer mortar," Sci. World J., vol. 2014, pp. 1-10, 2014, doi: 10.1155/2014/209584.

[48] S. Thokchom, P. Ghosh, and S. Ghosh, "Effect of water absorption, porosity and sorptivity on durability of geopolymer mortars," J. Eng. Appl. Sci., vol. 4, no. 7, pp. 28-32, 2009.

[49] P. Risdanareni, P. Puspitasari, D. Kartika, and B. Djatmika, "Mechanical properties of geopolymer paste with fly ash variation," AIP Conf. Proc., vol. 1778, no. October 2016, 2016, doi: 10.1063/1.4965759.

[50] Z. Xu, J. Yue, G. Pang, R. Li, P. Zhang, and S. Xu, "Influence of the Activator Concentration and Solid/Liquid Ratio on the Strength and Shrinkage Characteristics of Alkali-Activated Slag Geopolymer Pastes," Adv. Civ. Eng., vol. 2021, 2021, doi: 10.1155/2021/6631316.

[51] Mustofa, "The Effect of Si / Al Ratio to Compressive Strength and Water Absorption of Ferronickel," Int. Semin. Sci. Technol., pp. 167-172, 2016.

[52] M. El Alouani, S. Alehyen, M. El Achouri, A. Hajjaji, C. Ennawaoui, and M. Taibi, "Influence of the Nature and Rate of Alkaline Activator on the Physicochemical Properties of Fly Ash-Based Geopolymers," Adv. Civ. Eng., vol. 2020, 2020, doi: 10.1155/2020/8880906.

[53] A. Arham Adam, S. Amalia Namira, A. PN Siregar, and Mustofa, "The Effect of Activator to Binder Ratio on the Compressive Strength of Fly Ash Based Geopolymer Mortar in Sulphate Environment," MATEC Web Conf., vol. $331, \quad$ p. $05002, \quad 2020, \quad$ doi: 10.1051/matecconf/202033105002.

[54] A. A. Adam, "The Effects of Water to Solid Ratio, Activator to Binder Ratio, and Lime Proportion on the Compressive Strength of Ambient-Cured Geopolymer Concrete," J. Civ. Eng. Forum, vol. 5, no. 2, p. 161, 2019, doi: $10.22146 /$ jcef.43878. 
[55] Y. M. Liew, C. Y. Heah, A. B. Mohd Mustafa, and H. Kamarudin, "Structure and properties of clay-based geopolymer cements: A review," Prog. Mater. Sci., vol. 83, pp. 595-629, 2016, doi: 10.1016/j.pmatsci.2016.08.002.

[56] A. Solouki, G. Viscomi, R. Lamperti, and P. Tataranni, "Quarry waste as precursors in geopolymers for civil engineering applications: A decade in review," Materials (Basel)., vol. 13, no. 14, pp. 1-29, 2020, doi: $10.3390 / \mathrm{ma13143146}$

[57] A. Karthik, K. Sudalaimani, C. T. Vijayakumar, and S. S. Saravanakumar, "Effect of bio-additives on physico-chemical properties of fly ash-ground granulated blast furnace slag based self cured geopolymer mortars," $J$. Hazard. Mater., vol. 361, pp. 56-63, 2019, doi: 10.1016/j.jhazmat.2018.08.078.

[58] T. Suwan, "DEVELOPMENT OF SELF-CURED GEOPOLYMER CEMENT A thesis submitted for the degree of Doctor of Philosophy by Department of
Mechanical , Aerospace \&,” no. March, p. 60, 2016.

[59] S. Aydin and B. Baradan, "Mechanical and microstructural properties of heat cured alkali-activated slag mortars," Mater. Des., vol. 35, pp. 374-383, 2012, doi: 10.1016/j.matdes.2011.10.005.

[60] P. Risdanareni, P. Puspitasari, E. Santoso, and E. Prasetya Adi, "Mechanical and physical properties of metakaolin based geopolymer paste," MATEC Web Conf., vol. 101, pp. 1-5, 2017, doi: 10.1051/matecconf/201710101021.

[61] J. N. Yankwa Djobo, A. Elimbi, H. Kouamo Tchakouté, and S. Kumar, "Mechanical properties and durability of volcanic ash based geopolymer mortars," Constr. Build. Mater., vol. 124, pp. 606-614, 2016, doi: 10.1016/j.conbuildmat.2016.07.141.

[62] V. S. Le et al., "Mechanical properties of geopolymer foam at high temperature," Sci. Eng. Compos. Mater., vol. 27, no. 1, pp. 129-138, 2020, doi: 10.1515/secm-2020-0013. 